\title{
Characterization of Dental Pulp Stem Cells from Impacted Third Molars Cultured in Low Serum-Containing Medium
}

\author{
Jana Karbanováa, d Tomáš Soukup ${ }^{a} \quad$ Jakub Suchánek ${ }^{b}$ Robert Pytlík ${ }^{c}$ \\ Denis Corbeild Jaroslav Mokrýa \\ ${ }^{a}$ Department of Histology and Embryology, Charles University in Prague, Faculty of Medicine, and \\ ${ }^{b}$ Department of Dentistry, Faculty Hospital, Hradec Králové, and ' First Department of Internal Medicine, \\ Charles University in Prague, First Faculty of Medicine, Prague, Czech Republic; ${ }^{d}$ Tissue Engineering \\ Laboratories, BIOTEC, Technische Universität Dresden, Dresden, Germany
}

\section{Key Words}

Dental pulp stem cells - Neural differentiation - Osteoblast •

Chondroblast $\cdot$ Endothelial cells

\begin{abstract}
We isolated and expanded stem cells from dental pulp from extracted third molars using an innovative culture method consisting of low serum-containing medium supplemented with epidermal growth factor and platelet-derived growth factor BB. We evaluated the differentiation potential of these cells when they were growing either adherently or as micromass/spheroid cultures in various media. Undifferentiated and differentiated cells were analyzed by flow cytometry, immunocytochemistry and immunoblotting. The flow cytometry results showed that the dental pulp stem cells (DPSCs) were positive for mesenchymal stromal cell markers, but negative for hematopoietic markers. Immunocytochemical and/or immunoblotting analyses revealed the expression of numerous stem cell markers, including nanog, Sox2, nestin, Musashi-1 and nucleostemin, whereas they were negative for markers associated with differentiated neural, vascular and hepatic cells. Surprisingly, the cells were only slightly positive for $\alpha$-smooth muscle actin, and a heteroge-
\end{abstract}

\section{KARGER}

Fax +4161306 1234

E-Mail karger@karger.ch

www.karger.com
(C) 2010 S. Karger AG, Basel

$1422-6405 / 11 / 1936-0344 \$ 38.00 / 0$

Accessible online at:

www.karger.com/cto neous expression of CD146 was observed. When cultured in osteogenic media, they expressed osteonectin, osteopontin and procollagen I, and in micromass cultures, they produced collagen I. DPSCs cultured in TGF- $\beta 1 / 3$-supplemented media produced extracellular matrix typical of cartilaginous tissue. The addition of vascular endothelial growth factor to serumfree media resulted in the expression of endothelial markers. Interestingly, when cultured in neurogenic media, DPSCs exhibited de novo or upregulated markers of undifferentiated and differentiated neural cells. Collectively, our data show that DPSCs are self-renewing and able to express markers of bone, cartilage, vascular and neural tissues, suggesting their multipotential capacity. Their easy accessibility makes these cells a suitable source of somatic stem cells for tissue engineering.

Copyright $\odot 2010$ S. Karger AG, Basel

\section{Introduction}

During development, stem and progenitor cells actively proliferate to form tissues and organs, whereas in adults, they exist only as minute, often hidden, tissuespecific subpopulations that play a role in homeostasis. 


\begin{tabular}{|c|c|}
\hline \multicolumn{2}{|c|}{ Abbreviations used in this paper } \\
\hline$\alpha$-MEM & $\alpha$-minimum essential medium \\
\hline$\alpha-$ SMA & $\alpha$-smooth muscle actin \\
\hline $\mathrm{Ab}$ & antibody \\
\hline APC & allophycocyanin \\
\hline Bcrp1 & breast cancer resistant protein 1 \\
\hline BDNF & brain-derived neurotrophic factor \\
\hline bFGF & basic fibroblast growth factor \\
\hline BMP-2 & bone morphogenetic protein 2 \\
\hline CNTF & ciliary neurotrophic factor \\
\hline $\mathrm{DAB}$ & 3,3'-diaminobenzidine tetrahydrochloride \\
\hline DAPI & $4^{\prime}$-6-diamidino-2-phenylindole \\
\hline DMEM & Dulbecco's Modified Eagle's Medium \\
\hline DPSCs & dental pulp stem cells \\
\hline EGF & epidermal growth factor \\
\hline FCS & fetal calf serum \\
\hline FITC & fluorescein isothiocyanate \\
\hline FORSE-1 & forebrain surface embryonic-1 \\
\hline GAPDH & glyceraldehyde 3-phosphate dehydrogenase \\
\hline GDNF & glial cell-derived growth factor \\
\hline GFAP & glial fibrillary acidic protein \\
\hline $\operatorname{Ig}$ & immunoglobulin \\
\hline ITS & insulin, transferrin, selenite \\
\hline $\mathrm{NF}$ & neurofilaments \\
\hline NG2 & neuro-glial 2 \\
\hline NGF & nerve growth factor \\
\hline Oct- 4 & octamer-binding transcription factor 4 \\
\hline PBS & phosphate-buffered saline \\
\hline PDGF-BB & platelet-derived growth factor BB \\
\hline $\mathrm{PE}$ & phycoerythrin \\
\hline PFA & paraformaldehyde \\
\hline RIPA & radioimmunoprecipitation assay \\
\hline SDS-PAGE & $\begin{array}{l}\text { sodium dodecyl sulfate polyacrylamide gel elec- } \\
\text { trophoresis }\end{array}$ \\
\hline Sox-2 & SRY (sex determining region Y) box 2 \\
\hline SSEA & specific stage embryonic antigen \\
\hline TGF & transforming growth factor \\
\hline VEGF & vascular endothelial growth factor \\
\hline VEGFR2 & vascular endothelial growth factor receptor 2 \\
\hline vWF & von Willebrand factor \\
\hline
\end{tabular}

The dental cavity encloses a quite specific tissue type, dental pulp, that is well demarcated from surrounding tissues and, therefore, relatively easy to remove. Interestingly, in young adults, the dental pulp of impacted or nonerupted third molar teeth still contains immature tissue and, therefore, might represent a possible source of somatic stem cells.

Pioneering studies by Gronthos et al. [2000] have demonstrated the existence of stem cells within dental pulp. Following isolation based on plastic-adherence, they showed that dental pulp stem cells (DPSCs) have the ca-

Characterization of Dental Pulp Stem

Cells pacity to differentiate not only into odontoblasts, but also toward mesenchymal lineages (osteogenic and adipogenic potentials) [Gronthos et al., 2000, 2002; Miura et al., 2003]. Remarkably, upon the presentation of appropriate cues, DPSCs were observed to be able to differentiate toward becoming active neurons, making them a potential source for cell-based therapy to cure neurodegenerative diseases [Arthur et al., 2008]. The neuronal potential of DPSCs might be related to the cranial neural crest-cell origin of the dental pulp [Chai et al., 2000]. Moreover, certain embryonic stem cell markers (such as nanog, Oct-4, specific stage embryonic antigen-3 (SSEA-3), and SSEA-4) appeared to be expressed by isolated DPSCs, suggesting that they might have a multipotential capacity [Kerkis et al., 2006; Yalvac et al., 2010].

Until now, the experimental procedures used for the isolation and expansion of DPSCs have relied on culture media containing a high concentration of serum $(\geq 10 \%)$, which allows for better cell adhesion during the initial isolation of the cells [Gronthos et al., 2000; Kerkis et al., 2006; Yalvac et al., 2010]. However, for the long-term culture of DPSCs, which initially represent a minute population, the high level of serum might lead to spontaneous differentiation [Tseng et al., 2007; Gou et al., 2010] or malignant transformation [Rubio et al., 2005; Wang et al., 2005; Rosland et al., 2009]. Recently, we demonstrated that isolated DPSCs could be efficiently expanded in a low serum-containing (2\%) medium supplemented with epidermal growth factor (EGF) and platelet-derived growth factor BB (PDGF-BB) over Hayflick's limit while maintaining a stable karyotype [Suchanek et al., 2007]. The use of growth factors (EGF and PDGF-BB) has been reported to stimulate proliferation of both bone marrow stromal cells and multipotent adult progenitor cells [Gronthos and Simmons, 1995; Reyes et al., 2002].

Here, we present evidence that DPSCs cultured ex vivo under these conditions (that is, low level of serum) fully maintain their differentiation capacities toward osteogenic, chondrogenic, endothelial, smooth muscle and neural lineages. Thus, they might represent an accessible and reliable source of stem cells for tissue engineering and cell-based replacement.

\section{Material and Methods}

\section{Antibodies}

The primary antibodies (Abs) used for immunodetection are listed in table 1 , and the secondary Abs used were $\mathrm{Cy}^{\mathrm{TM}}$-conjugated AffiniPure donkey anti-mouse $\operatorname{IgG}(\mathrm{H}+\mathrm{L})$ and anti-goat 
Table 1. Primary antibodies used for immunodetection

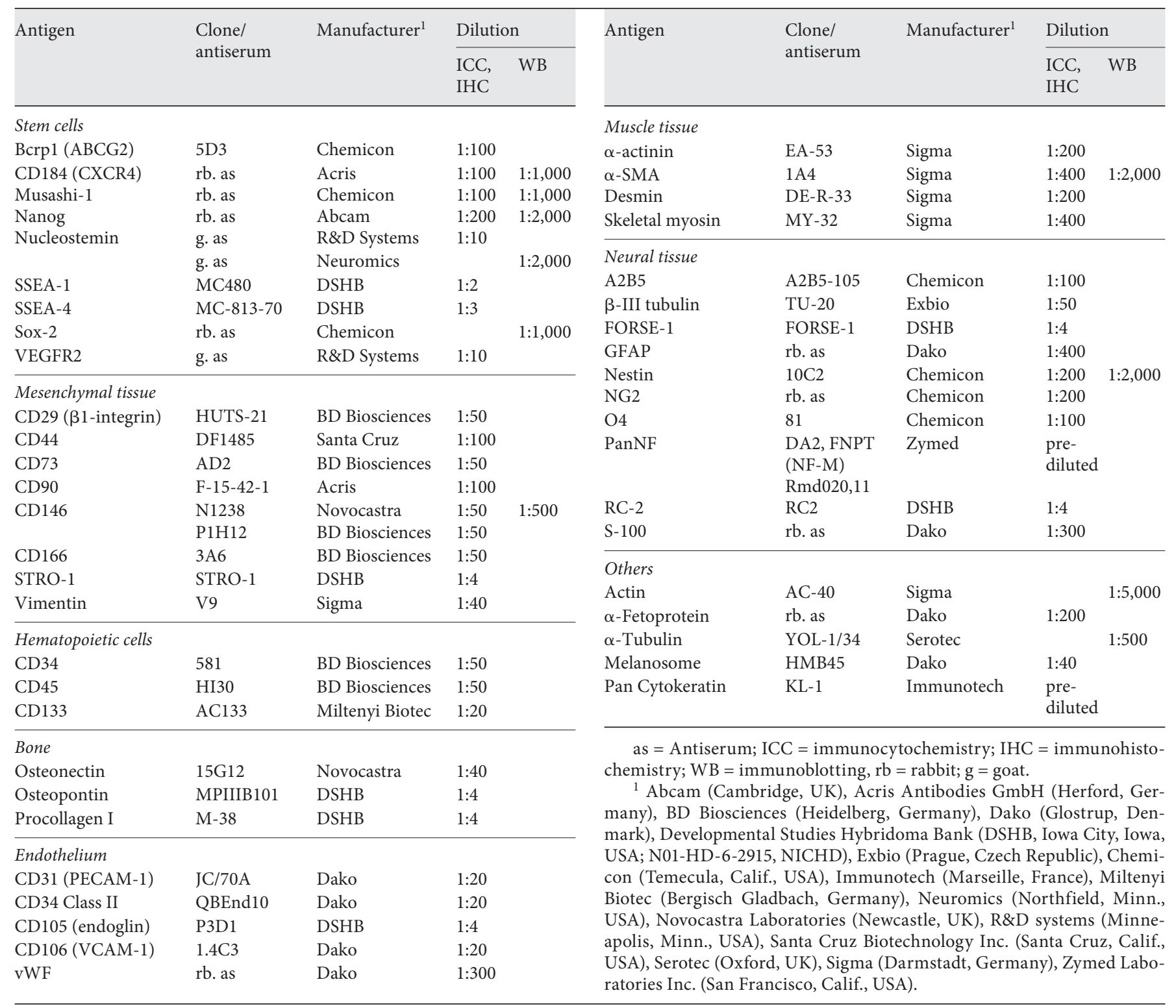

IgG $(\mathrm{H}+\mathrm{L})$, Cy3 $3^{\mathrm{TM}}$-conjugated goat anti-mouse IgM (Jackson Immunoresearch, West Grove, Pa., USA), Alexa Fluor ${ }^{\circledR} 488$-conjugated goat anti-mouse IgG and anti-rabbit IgG, donkey anti-goat IgG (Molecular Probes, Invitrogen Corp., Carlsbad, Calif., USA) and the anti-mouse or anti-rabbit EnVision peroxidase kit (Dako, Glostrup, Denmark). As controls, isotype IgG1к (MOPC-21; Sigma, Darmstadt, Germany) and IgG2ак (MOPC-173; Abcam, Cambridge, UK) were used. For immunoblotting, horseradish peroxidase-conjugated AffiniPure rabbit anti-mouse IgG, goat anti-rabbit IgG and mouse anti-goat IgG (Jackson Immunoresearch) were used.

\section{Media Components}

The composition of all media mentioned below is listed in table 2. Ascorbic acid 2-phosphate, $\beta$-glycerophosphate, dexamethasone, ITS and ITS+1 supplements as well as proline were purchased from Sigma; $\alpha$-MEM, high-glucose DMEM and neurobasal medium, B27 supplement, L-glutamine, penicillin/streptomycin and sodium pyruvate were from Gibco (Paisley, UK); fetal calf serum (FCS) was from PAA Laboratories (Linz, Austria), human recombinant transforming growth factor $\beta 1 / 3$ (TGF- $\beta 1 / 3$ ) was from R\&D Systems (Minneapolis, Minn., USA); human recombinant basic fibroblast growth factor (bFGF), bone morphogenetic protein (BMP-2), EGF, PDGF and vascular endothelial growth factor (VEGF) were from PeproTech (London, UK). 
Table 2. List and composition of cultivation media

\begin{tabular}{|c|c|c|c|}
\hline Basic & $\alpha-\mathrm{MEM}$ & & $\begin{array}{l}0.2 \mathrm{mM} \text { ascorbic acid } 2 \text {-phosphate } \\
50 \mathrm{nM} \text { dexamethasone } \\
2 \mathrm{mM} \text { L-glutamine } \\
100 \mathrm{U} / \mathrm{ml} \text { penicillin; } 100 \mu \mathrm{g} / \mathrm{ml} \text { streptomycin }\end{array}$ \\
\hline Basic expansion & basic & $2 \%$ & $\begin{array}{l}10 \mathrm{ng} / \mathrm{ml} \text { EGF } \\
10 \mathrm{ng} / \mathrm{ml} \text { PDGF-BB }\end{array}$ \\
\hline Standard & $\alpha-\mathrm{MEM}$ & $10 \%$ & $\begin{array}{l}0.2 \mathrm{mM} \text { ascorbic acid } 2 \text {-phosphate } \\
2 \mathrm{mM} \text {-glutamine } \\
100 \mathrm{U} / \mathrm{ml} \text { penicillin; } 100 \mu \mathrm{g} / \mathrm{ml} \text { streptomycin }\end{array}$ \\
\hline Osteogenic & $\alpha-\mathrm{MEM}$ & $10 \%$ & $\begin{array}{l}0.2 \mathrm{mM} \text { ascorbic acid } 2 \text {-phosphate } \\
2 \mathrm{mM} \mathrm{L} \text {-glutamine } \\
100 \mathrm{U} / \mathrm{ml} \text { penicillin; } 100 \mu \mathrm{g} / \mathrm{ml} \text { streptomycin } \\
10 \mathrm{mM} \text {-glycerophosphate } \\
0.1 \mu \mathrm{M} \text { dexamethasone }\end{array}$ \\
\hline Chondrogenic B & $\begin{array}{l}\text { high glucose } \\
\text { DMEM }\end{array}$ & & $\begin{array}{l}0.2 \mathrm{mM} \text { ascorbic acid } 2 \text {-phosphate } \\
0.1 \mu \mathrm{M} \text { dexamethasone } \\
1 \% \mathrm{ITS}+1 \text { supplement } \\
100 \mathrm{U} / \mathrm{ml} \text { penicillin; } 100 \mu \mathrm{g} / \mathrm{ml} \text { streptomycin } \\
40 \mu \mathrm{g} / \mathrm{ml} \text { proline } \\
100 \mu \mathrm{g} / \mathrm{ml} \text { sodium pyruvate } \\
10 \mathrm{ng} / \mathrm{ml} \mathrm{TGF-} \beta 3\end{array}$ \\
\hline Endothelial & basic & {$[10 \%]$} & $\begin{array}{l}\text { 1\% ITS supplement } \\
20 \mathrm{ng} / \mathrm{ml} \text { VEGF }\end{array}$ \\
\hline Smooth muscle cell/myofibroblast & basic & & 10 ng/ml TGF- $\beta 1$ \\
\hline Neurogenic expansion & neurogenic & $1 \%$ & [50 ng/ml BMP-2] \\
\hline
\end{tabular}

Square brackets show optional components.

\section{Cell Isolation and Culture}

DPSCs were isolated from impacted third molars of healthy young donors $(n=9)$ aged $17-23$ years undergoing tooth extraction for orthodontic reasons [Suchanek et al., 2007]. All tissue materials were acquired under informed consent and processed according to guidelines approved by the Ethical Committee of the Faculty Hospital in Hradec Králové. DPSCs were isolated as described previously [Gronthos et al., 2000; Suchanek et al., 2007]. Briefly, removed pulp tissue was digested with collagenase $(0.2$ $\mathrm{mg} / \mathrm{ml}$; Sevapharma, Prague, Czech Republic) and dispase (2 mg/ $\mathrm{ml}$; Gibco) for $70 \mathrm{~min}$ at $37^{\circ} \mathrm{C}$, mechanically dissociated and filtered through a $70-\mu \mathrm{m}$ cell strainer (BD Falcon; BD Biosciences, Heidelberg, Germany). Pulp cell suspensions were generally cul- tured in a basic expansion medium (table 2). The medium was changed every 2 or 3 days. The first passage was done when single colonies appeared (that is, after 5-10 days), and afterwards, cells were trypsinized upon reaching $70 \%$ confluence. Cells were split $1: 3$. In some experiments, freshly isolated cells were cultured in a standard medium (table 2).

\section{DPSC Differentiation}

Dental pulp-derived cells were initially cultured in basic expansion medium for at least one passage prior to differentiation. The following media and conditions were used for the ex vivo differentiation of DPSCs. 


\section{Osteodifferentiation}

DPSCs growing as either a confluent cell monolayer or a micromass high-density cell culture, which was generated by spontaneous cell aggregation $\left(10^{6}\right.$ cells) in round-bottomed $4-\mathrm{ml}$ culture tubes, were differentiated using osteogenic medium (table 2) [Pittenger et al., 1999]. The medium was exchanged every 2-3 days.

\section{Chondrodifferentiation}

DPSCs growing as a micromass culture $\left(10^{6}\right.$ cells $)$ were differentiated using two alternative media, A or B (table 2) [Mackay et al., 1998]. Media were exchanged every 2-3 days.

\section{Endothelial Differentiation}

DPSCs were plated at a density of $2 \times 10^{4} / \mathrm{cm}^{2}$ on polyornithine/fibronectin-coated coverslips and cultured in serum-free endothelial medium (table 2). The medium was exchanged every 2-3 days. In some experiments, after 10 days, $10 \%$ FCS was added to the medium and cells were further expanded for 10-21 days.

\section{Smooth Muscle Cell/Myofibroblast Differentiation}

DPSCs were cultured in smooth muscle cell/myofibroblast differentiation medium (table 2). Media were exchanged every 2 days.

\section{Neural Differentiation}

DPSCs were cultured as a cell monolayer in neurogenic expansion medium (table 2 ) for at least 3 passages. After that, cells were further cultured as a monolayer either in neurogenic (table 2) or neurogenic expansion medium supplemented with (or without) BMP-2 (PeproTech) or as spheroids in nontreated T-flasks (Sarstedt, Nümbrecht, Germany). Media were exchanged every 2-3 days.

\section{Cytochemistry}

Cells growing on polyornithine/fibronectin-coated coverslips were washed 3 times in PBS and then fixed with $4 \%$ paraformaldehyde (PFA) in PBS at $4^{\circ} \mathrm{C}$ for $10 \mathrm{~min}$, methanol/acetone at $-20^{\circ} \mathrm{C}$ for $5 \mathrm{~min}$ or using a combination of both protocols. After thorough washing with PBS, cells were permeabilized with $0.1 \%$ Triton X-100 for $10 \mathrm{~min}$ at room temperature (only for the PFA fixation protocol), blocked in PBS containing either 5\% normal goat (Sigma) or donkey serum (Jackson Immunoresearch) and then incubated with a given primary $\mathrm{Ab}$ (table 1 ) at $4^{\circ} \mathrm{C}$ overnight. As a negative control, the primary Ab was omitted. After washing, cells were incubated with the appropriate fluorochrome-conjugated species-specific secondary $\mathrm{Ab}$ at room temperature for 45 min. Nuclei were counterstained with 4'-6-diamidino-2-phenylindole (DAPI; Sigma). Coverslips were mounted in polyvinyl alcohol/glycerol containing the antifading agent 1,4-diazobicyclo[2.2.2]-octane. Samples were examined using a BX51 Olympus microscope equipped with an Olympus DP71 digital camera, and the images were prepared using Adobe ${ }^{\circledR}$ Photoshop and Illustrator software.

\section{Cell Surface Immunofluorescence}

Cell surface labeling was performed as described previously [Corbeil et al., 2000]. Briefly, cells grown on coverslips were washed twice with PBS followed by ice-cold Ca/Mg-PBS (PBS containing $1 \mathrm{mM} \mathrm{CaCl}_{2}, 0.5 \mathrm{mM} \mathrm{MgCl}_{2}$ ) and then incubated with primary Abs (table 1) diluted in immunofluorescence buffer $(\mathrm{Ca} /$ $\mathrm{Mg}$-PBS containing $0.2 \%$ gelatin) for $30 \mathrm{~min}$ at $4^{\circ} \mathrm{C}$. Unbound $\mathrm{Abs}$ were removed by 5 washes with ice-cold immunofluorescence buffer. Fixative, $4 \%$ PFA in PBS, was added to the cells on ice, and the coverslips were placed at room temperature for $15 \mathrm{~min}$. The fixative was removed by 3 washes with $\mathrm{Ca} / \mathrm{Mg}-\mathrm{PBS}$, and the residual PFA was quenched with $50 \mathrm{mM} \mathrm{NH}_{4} \mathrm{Cl}$ for $10 \mathrm{~min}$. The cells were then incubated with $\mathrm{Cy} 3^{\mathrm{TM}}$-conjugated anti-mouse secondary $\mathrm{Ab}$ for $30 \mathrm{~min}$ at room temperature. After washing in PBS, nuclei were counterstained with DAPI, and coverslips were rinsed sequentially with PBS and distilled water and mounted in Mowiol (Merck, Darmstadt, Germany).

\section{Histochemistry}

Dental pulp removed from the dental cavity or DPSCs growing either as micromass cultures or multilayered nodules were fixed with $10 \%$ formalin and embedded in paraffin. Serial sections $(5-6 \mu \mathrm{m})$ were cut, mounted on glass slides pretreated with chrome alum-gelatin, and dried at room temperature overnight. Paraffin-embedded sections were deparaffinized by xylol treatment, hydrated with decreasing concentrations of ethanol (96, 80 and $70 \%$ ), and then rinsed twice with distilled water.

Spheroid cultures were fixed in $4 \%$ PFA in PBS for $30 \mathrm{~min}$, cryoprotected by treatment in $20 \%$ sucrose in PBS for $2 \mathrm{~h}$, embedded in TissueTek ${ }^{\circledR}$ OCT ${ }^{\text {TM }}$ compound (Sakura Finetek, Staufen, Germany), processed for cryosections, and mounted on slides pretreated with 3-aminopropyltriethoxysilane (Sigma). Cryosections were permeabilized with $0.1 \%$ Triton X-100 for $10 \mathrm{~min}$ at room temperature. For peroxidase immunodetection, endogenous peroxidase activity was quenched, and samples were further processed as described below. For fluorescent immunodetection, permeabilized sections were blocked in PBS containing 5\% normal goat serum (Sigma), immunolabeled and mounted as described (see Cytochemistry section).

For antigen retrieval, deparaffinized sections were exposed to microwaves $(700 \mathrm{~W})$ in sodium citrate solution $(\mathrm{pH}=6.0) 2$ times, for $5 \mathrm{~min}$ each. After extensive washing with distilled water, endogenous peroxidase activity was quenched by incubating samples in $3 \% \mathrm{H}_{2} \mathrm{O}_{2}(3 \times 10 \mathrm{~min})$. Sections were then incubated in blocking buffer (5\% normal goat serum in PBS) for $20 \mathrm{~min}$ and exposed to primary Ab (table 1) diluted in Antibody Diluent with Background Reducing Components (Dako) at $4{ }^{\circ} \mathrm{C}$ overnight. As negative controls, matching mouse isotype controls were used or the primary Ab was omitted. After washing with PBS, sections were incubated with reagents from either an anti-mouse or antirabbit EnVision peroxidase kit according to the manufacturer's protocol. Color reactions were performed using the chromogen $\operatorname{DAB}\left(3,3^{\prime}\right.$-diaminobenzidine tetrahydrochloride, $2 \mu \mathrm{g} / \mathrm{ml}$; Fluka, Darmstadt, Germany). After washing with distilled water, DAB precipitate was intensified with $3 \% \mathrm{CuSO}_{4}$ solution for $5 \mathrm{~min}$. Sections were then counterstained with either Mayer's hematoxylin (Merck) or light green (BDH Stains, Poole, UK), dehydrated and mounted in DPX (Fluka).

In osteoids, collagen I was detected using blue trichrome staining modified according either to Masson or Ladewig. Calcium phosphate was detected using von Kossa staining. Acid mucins were visualized by Alcian blue staining (1\% Alcian blue solution in $3 \%$ acetic acid, $30 \mathrm{~min})$. Tissues were then dehydrated and mounted in DPX (Fluka). 
Table 3. List of primers used for RT-PCR analysis

\begin{tabular}{|c|c|c|c|c|}
\hline Gene & $\begin{array}{l}\text { Accession } \\
\text { number }\end{array}$ & $\begin{array}{l}\text { Forward primer }\left(5^{\prime} \rightarrow 3^{\prime}\right) \\
\text { Reverse primer }\left(5^{\prime} \rightarrow 3^{\prime}\right)\end{array}$ & $\begin{array}{l}\text { Product } \\
\text { size, bp }\end{array}$ & $\begin{array}{l}\text { Annealing } \\
\text { temperature, }{ }^{\circ} \mathrm{C}\end{array}$ \\
\hline Oct- $4^{1}$ & NM_002701 & $\begin{array}{l}\text { CGACCATCTGCCGCTTTGAG } \\
\text { CCCCCTGTCCCCCATTCCTA }\end{array}$ & 573 & 64 \\
\hline Nanog & NM_024865 & $\begin{array}{l}\text { GGCAAACAACCCACTTCTGC } \\
\text { CAGGACTGGATGTTCTGGGTCT }\end{array}$ & 428 & 62 \\
\hline Sox-2 & NM_003106 & $\begin{array}{l}\text { CCGTTCATCGACGAGGCTAAG } \\
\text { TGCTGCGAGTAGGACATGCTG }\end{array}$ & 425 & 62 \\
\hline Bone sialoprotein & NM_004967 & $\begin{array}{l}\text { CACCACAGAGACCGGAAGGC } \\
\text { TCCCAGGCTGGAGCTTCACT }\end{array}$ & 331 & 62 \\
\hline Osteocalcin & NM_199173 & $\begin{array}{l}\text { ACACCATGAGAGCCCTCACA } \\
\text { AGCAGAGCGACACCCTAGAC }\end{array}$ & 322 & 62 \\
\hline Aggrecan & NM_001135 & $\begin{array}{l}\text { ACTGCTGCAGACCAGGAGGT } \\
\text { TTGTAGGTGGTGGCTGTGCC }\end{array}$ & 410 & 62 \\
\hline $\begin{array}{l}\text { Collagen II } \\
(C O L 2 A 1)\end{array}$ & NM_001844 & $\begin{array}{l}\text { GCTATGGAGATGACAATCTGGC } \\
\text { CTCGGGCCCTCCTATGTCCA }\end{array}$ & 344 & 62 \\
\hline $\mathrm{GAPDH}^{2}$ & NM_002046 & $\begin{array}{l}\text { CGGGAAGCTTGTCATCAATGG } \\
\text { GGCAGTGATGGCATGGACTG }\end{array}$ & 358 & 62 \\
\hline
\end{tabular}

${ }^{1}$ Primers designed according to McLaughlin et al. [2006]. ${ }^{2}$ Primers designed according to Kudo et al. [1998].

\section{Flow Cytometry}

DPSCs were harvested by trypsin/EDTA treatment for $5 \mathrm{~min}$ at $37^{\circ} \mathrm{C}$. After inactivation of trypsin and centrifugation $(5 \mathrm{~min}$ at $300 \mathrm{~g}), 100 \mu \mathrm{l}$ of the cell suspensions $\left(10^{5}\right.$ cells) were incubated for $30 \mathrm{~min}$ at $4^{\circ} \mathrm{C}$ with the following fluorochrome-conjugated Abs: CD29-phycoerythrin (PE; HUTS-21), CD34-allophycocyanin (APC; clone 581), CD44-fluorescein isothiocyanate (FITC; G44-26), CD45-PE (HI30), CD73-PE (AD2), CD90-FITC (5E10), CD146-PE (P1H12), CD166-PE (3A6; all from BD Biosciences); CD29-PE (MEM-101A; Invitrogen); CD133-APC (AC133-1) and CD146-APC (541-10B2; both from Miltenyi Biotec, Bergisch Gladbach, Germany). After washing with PBS, 10,000 events were acquired on an LSRII flow cytometer (BD Biosciences). Instrument settings and gating strategies were established using isotype controls, and data were analyzed using FlowJo software (TreeStar, Ashland, Oreg., USA).

\section{Protein Extraction and Immunoblotting}

Cells were washed and scraped in ice-cold PBS, followed by their solubilization in RIPA buffer ( $1 \%$ NP-40, 0.5\% deoxycholate, $0.1 \%$ sodium dodecylsulfate, $150 \mathrm{mM} \mathrm{NaCl}, 50 \mathrm{~mm}$ Tris- $\mathrm{HCl}, \mathrm{pH}$ 8.0) in the presence of $1 \mathrm{~mm}$ phenylmethylsulfonyl fluoride and complete protease inhibitors (Roche, Basel, Switzerland) for $30 \mathrm{~min}$ at $4^{\circ} \mathrm{C}$. After centrifugation $(10 \mathrm{~min}, 16,000 \mathrm{~g})$, the protein concentration in supernatant was determined using a BSA protein assay (Pierce Biotechnology, Rockford, Ill., USA). Proteins from each sample $(25 \mu \mathrm{g})$ were resuspended in Laemmli sample buffer, heated for $5 \mathrm{~min}$ at $95^{\circ} \mathrm{C}$, separated by SDS-PAGE $(7.5 \%)$ and transferred to a polyvinylidene fluoride membrane (pore size
$0.45 \mu \mathrm{m}$; Millipore, Schwalbach, Germany), as previously described [Corbeil et al., 2001]. Membranes were incubated at $4^{\circ} \mathrm{C}$ overnight in blocking buffer (PBS containing 5\% low fat milk powder and $0.3 \%$ Tween 20 ) and then probed with a given primary $\mathrm{Ab}$ (table 1 ) for $1 \mathrm{~h}$ at room temperature. Antigen-Ab complexes were detected using the appropriate horseradish peroxidase-conjugated secondary $\mathrm{Ab}$ and visualized with enhanced chemiluminescence-developing reagents (ECL system; Amersham Corp., Arlington Heights, Ill., USA). Membranes were generally exposed for 1-10 min to autoradiographic films (Hyperfilm ECL; Amersham-Pharmacia).

\section{RT-PCR Analysis}

Total RNA was prepared from undifferentiated as well as osteo- and chondrodifferentiated DPSCs using an RNeasy Mini Kit with column DNAase treatment according to the manufacturer's instructions (Qiagen $\mathrm{GmbH}$, Hilden, Germany). cDNA was synthesized using a High-Capacity cDNA Reverse Transcription Kit (Applied Biosystems, Foster City, Calif., USA) from $1 \mu \mathrm{g}$ of total RNA in a $20-\mu l$ reaction volume, followed by PCR using Platinum Taq DNA polymerase (Invitrogen) for gene amplification. PCR was performed using a Mastercycler ep gradient $S$ (Eppendorf, Hamburg, Germany) for 35 cycles consisting of 45 s denaturation, $94^{\circ} \mathrm{C}$; $45 \mathrm{~s}$ annealing, $62^{\circ} \mathrm{C}$; $90 \mathrm{~s}$ extension, $72^{\circ} \mathrm{C}$; with initial denaturation for $5 \mathrm{~min}, 94^{\circ} \mathrm{C}$ and final extension for $10 \mathrm{~min}, 72^{\circ} \mathrm{C}$. The primer pairs used are listed in table 3. After PCR, $5-\mu l$ aliquots of the products were subjected to $1.7 \%$ agarose gel electrophoresis, stained with ethidium bromide and visualized by UV illumination. 
Statistical Analysis

Statistical analysis was performed using Wilcoxon signedrank test. A probability of $\mathrm{p} \leq 0.05$ was considered as statistically significant.

\section{Results}

\section{Characterization of Cultured DPSCs}

DPSCs were isolated from dissociated dental pulp on the basis of their adhesion to a plastic substratum as previously described [Gronthos et al., 2000]. Upon being cultured in low serum-containing medium (2\% FCS) supplemented with EGF and PDGF-BB, hereafter referred to as basic expansion medium, the fresh pulp cell suspensions contained both single cells and multicellular structures (fig. 1a). During the first 48-72 h, cells adhered (fig. 1b, c) but they proliferated poorly (data not shown). Colonies were observed after 5-7 days (fig. 1d). Cells generally exhibited a fibroblast-like morphology. Interestingly, they started to proliferate and generated a monolayer upon the first passage (fig. 1e). Without serum in the culture medium, the initial cell adhesion was altered, and similarly no expansion was observed in the absence of EGF and PDGF-BB (data not shown).

Next, we evaluated the antigenic profile of undifferentiated DPSCs by 3 distinct, but complementary, methods, namely immunocytochemistry (fig. 1, 2, 6-8; table 4), flow cytometry (fig. 2; table 5, 6) and immunoblotting (fig. 3a-c). The data are compiled in table 4. DPSCs displayed a high expression of markers associated with mesenchymal stromal cells, such as STRO-1, vimentin, CD29, CD44, CD73, CD90 and CD166 (fig. 1f, g, 2a). Their expression appeared independent of the number of passages (up to 20) and donors (table 5). In contrast, the expression of CD146 varied in the intensity (fig. 2a), and in the number of positive cells among donors ranging between 0 and $38 \%$ (tables 5, 6). DPSCs expressed numerous neural-associated stem cell markers such as nestin, nucleostemin, Musashi-1 and chondroitin sulfate proteoglycan NG2 (neuro-glial 2; fig. 1h-k). Other markers associated with stem cells, for example, chemokine receptor CXCR4 and VEGF receptor 2 (VEGFR2), were expressed as well (fig. 1l, m). Bcrp1 was weakly and heterogeneously expressed (fig. 8d, inset). Less than $1 \%$ of these cells were positive for forebrain surface embryonic-1 (FORSE1; fig. 8c, inset), SSEA-1 and SSEA-4 (fig. 1n, o). However, they strongly expressed other markers associated with embryonic stem cells, including nanog and Sox-2 (fig. 1p, q). Finally, DPSCs were negative for the hematopoietic markers CD34, CD45 and CD133 (fig. 2b; table 5) or negative/weakly positive for markers associated with differentiated or lineage-committed cells, such as $\alpha$-smooth muscle actin ( $\alpha$-SMA, fig. $4 a)$, glial fibrillary acidic protein (GFAP), A2B5, O4, PanNF (neurofilaments), $\beta$-III tubulin (fig. 8h, e, i-k, insets), osteopontin, osteonectin, procollagen I (fig. 6a-c, insets), von Willebrand factor, CD31, CD105 and CD106 (fig. 7a, c-f, insets; table 4). The immunoblotting experiments and RT-PCR analyses confirmed that both the protein and/or transcripts of the major markers associated with neural and embryonic stem cells including Oct-4, nanog and Sox-2 were expressed (fig. 3a-c, lane 1; 3d, lanes 1-3).

Compared to DPSCs that are isolated and expanded in culture media containing a higher concentration of serum $(10-20 \%)$ as used in earlier studies [Gronthos et al., 2000; Kerkis et al., 2006; Yalvac et al., 2010], which may allow for better cell adhesion and, hence, the isolation of a larger cell population, the expression of early stem cell markers by cells isolated in low serum-containing media indicated that the use of a lower serum concentration is not disadvantageous. Nevertheless, when $10 \%$ instead of $2 \%$ FCS was used, we observed that the expression level of 3 of the markers examined appeared to be altered (fig. 3a, b, lane 1 vs. 2). Nestin and Sox-2 were decreased, whereas Musashi-1 was increased in cells derived from culture containing high versus low amounts of serum (fig. 3a, b). The expression of nucleostemin, NG2, nanog and CXCR4 remained constant (fig. 3a-c). RT-PCR confirmed these trends (fig. 3d). More strikingly, the expression level of CD146, which has shown great variability in our culture system (see above), and $\alpha$-SMA were significantly lower in cells isolated and cultured in the low serum-containing media compared to high serum-content media (fig. 4b, lane 1 (BE) vs. 7 (S)). Interestingly, shifting the culture media of DPSCs already isolated and cultured in medium containing low amounts of serum $(2 \%)$ to one containing high amounts of serum (10\%) did not cause a major upregulation of these markers (by comparison to those isolated and cultured in high serum content), even after 5 passages (fig. $4 a, b, B E \rightarrow S$ ), suggesting that serum per se has a limited effect on their activation.

To gain more insight into the potential origin of DPSCs in situ, we performed immunohistochemistry on paraffin-embedded sections of dental pulp from impacted third molars (fig. 5). Interestingly, we could distinguish at least 4 possible and/or alternative sources of DPSCs according to the localization of proteins that are expressed ex vivo (fig. 1-4). First, perivacular cells had the molecular signature $\alpha$-SMA, CD146, Musashi-1, 

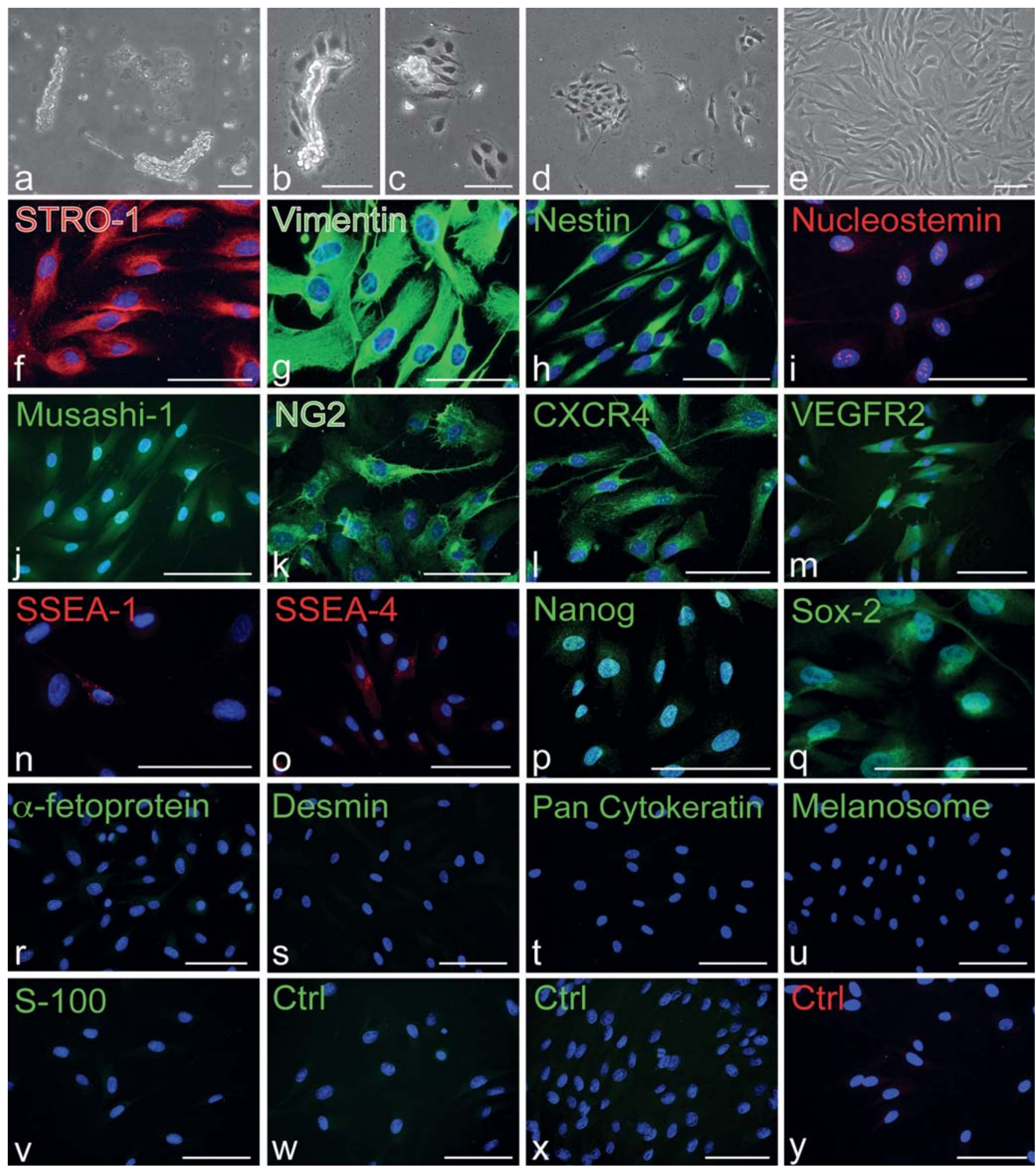

Fig. 1. Immunocytochemistry of cultured DPSCs. Dental pulpderived, undifferentiated DPSCs cultured in basic expansion medium were observed by phase contrast microscopy after 5 (a) and $72 \mathrm{~h}(\mathbf{b}, \mathbf{c})$ and 7 days (d) in culture or $48 \mathrm{~h}$ after their first passage (e). The expression of several antigenic markers, as indicated, was monitored from the 3rd to the 6th passage by indirect immuno- fluorescence microscopy (f-v). As a negative control (Ctrl), Alexa Fluor 488-conjugated anti-mouse or anti-rabbit IgG and Cy3conjugated anti-mouse IgM secondary Abs were used alone ( $\mathbf{w}-\mathbf{y}$, respectively). Nuclei were visualized with DAPI (blue; f-y). Representative examples based on the evaluation of at least 4 donors are shown. Scale bars $=50 \mu \mathrm{m}$. 

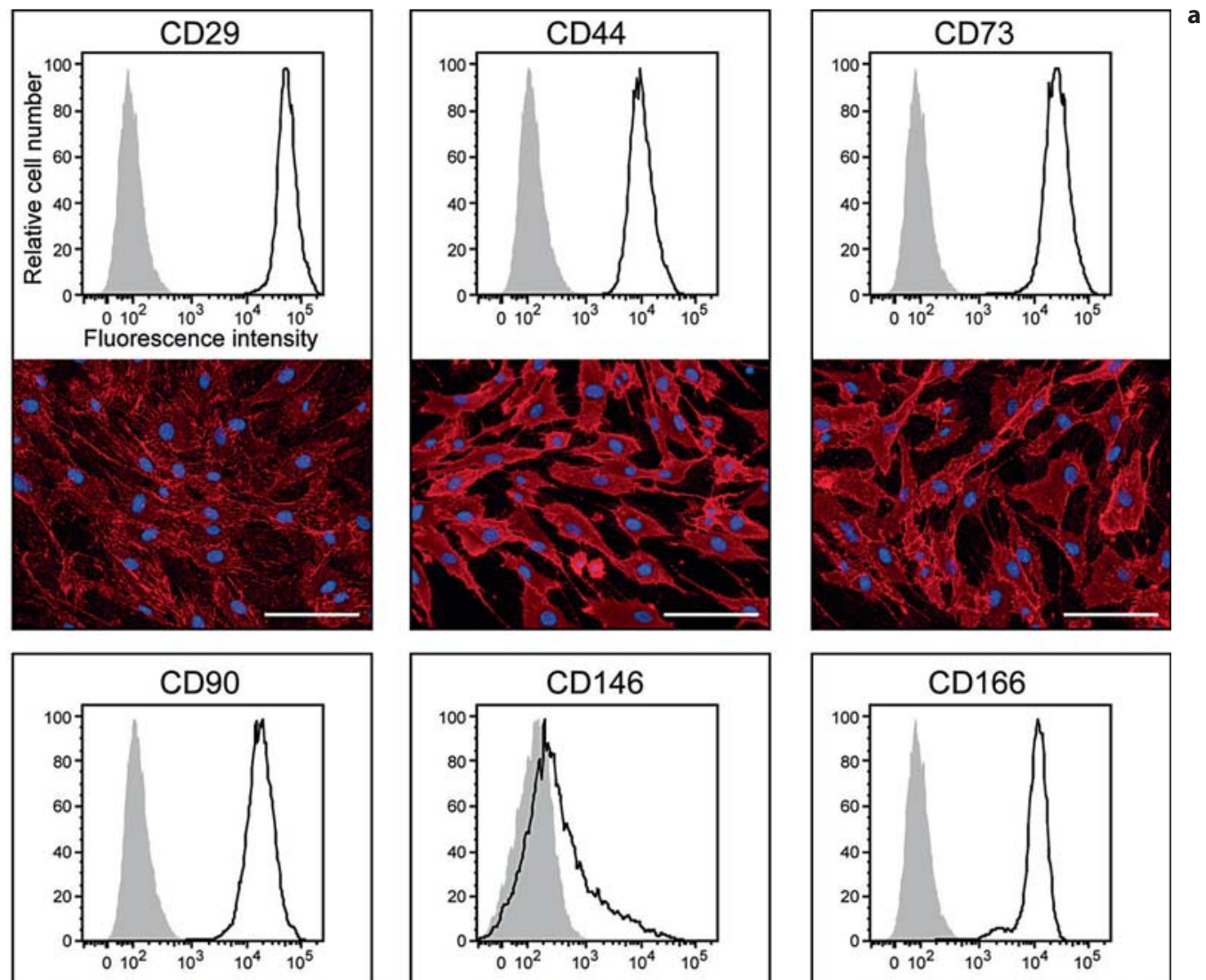

Fig. 2. Flow cytometry and cell surface immunofluorescence of cultured DPSCs. Undifferentiated DPSCs cultured in basic expansion medium were either trypsinized and analyzed by flow cytometry, or intact cells were directly labeled at $4^{\circ} \mathrm{C}$ using a panel of mesenchymal (a) or hematopoietic (b) cell surface markers, as indicated. For the flow-cytometric analysis, the antigen expression (open area) and the appropriate isotypematching control (grey filled area) are depicted in the upper panels. The corresponding immunofluorescence labeling is presented in the lower panels. A representative experiment is shown $(\mathrm{n}=4)$. Scale bars $=50$ $\mu \mathrm{m}$.
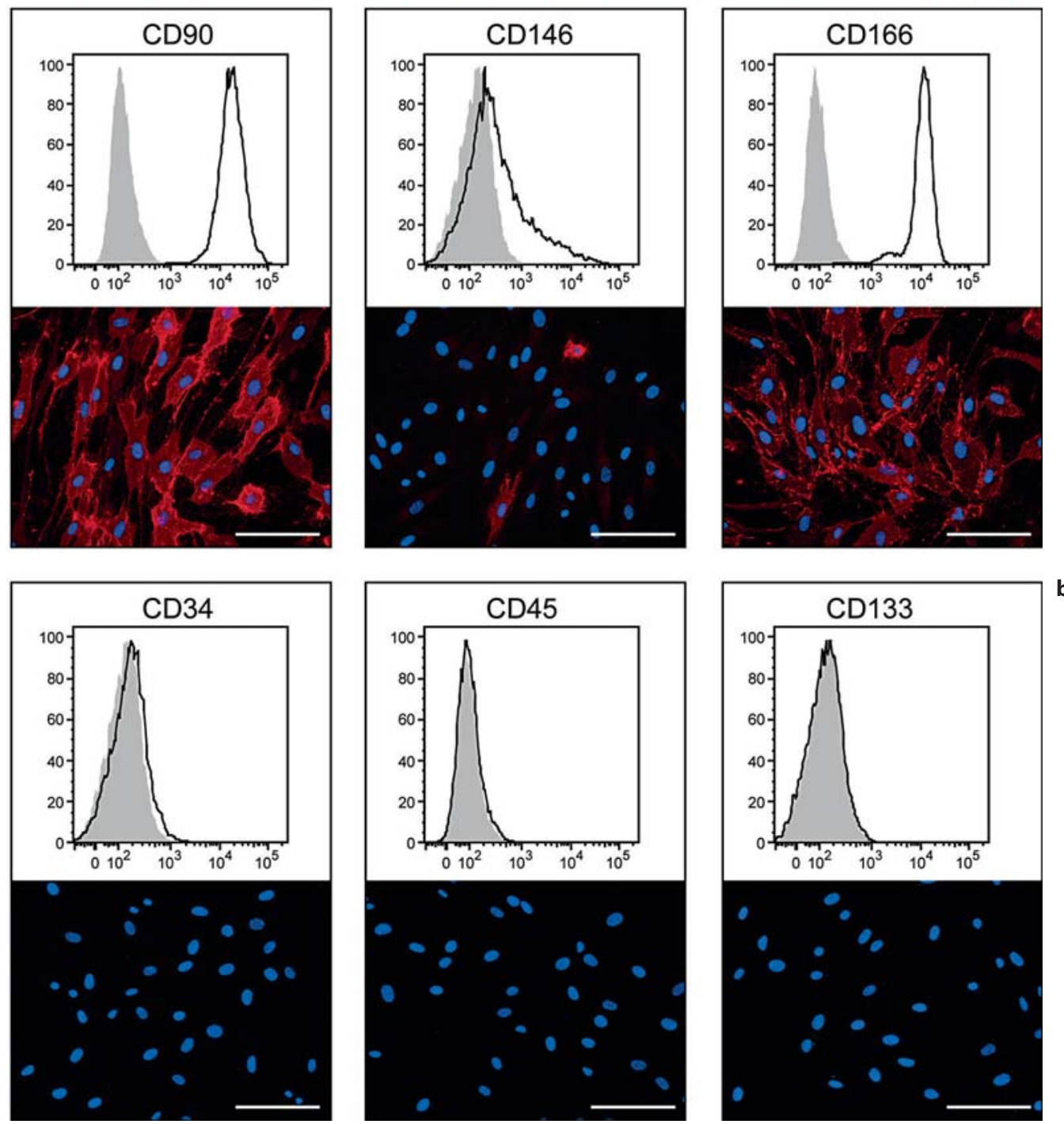


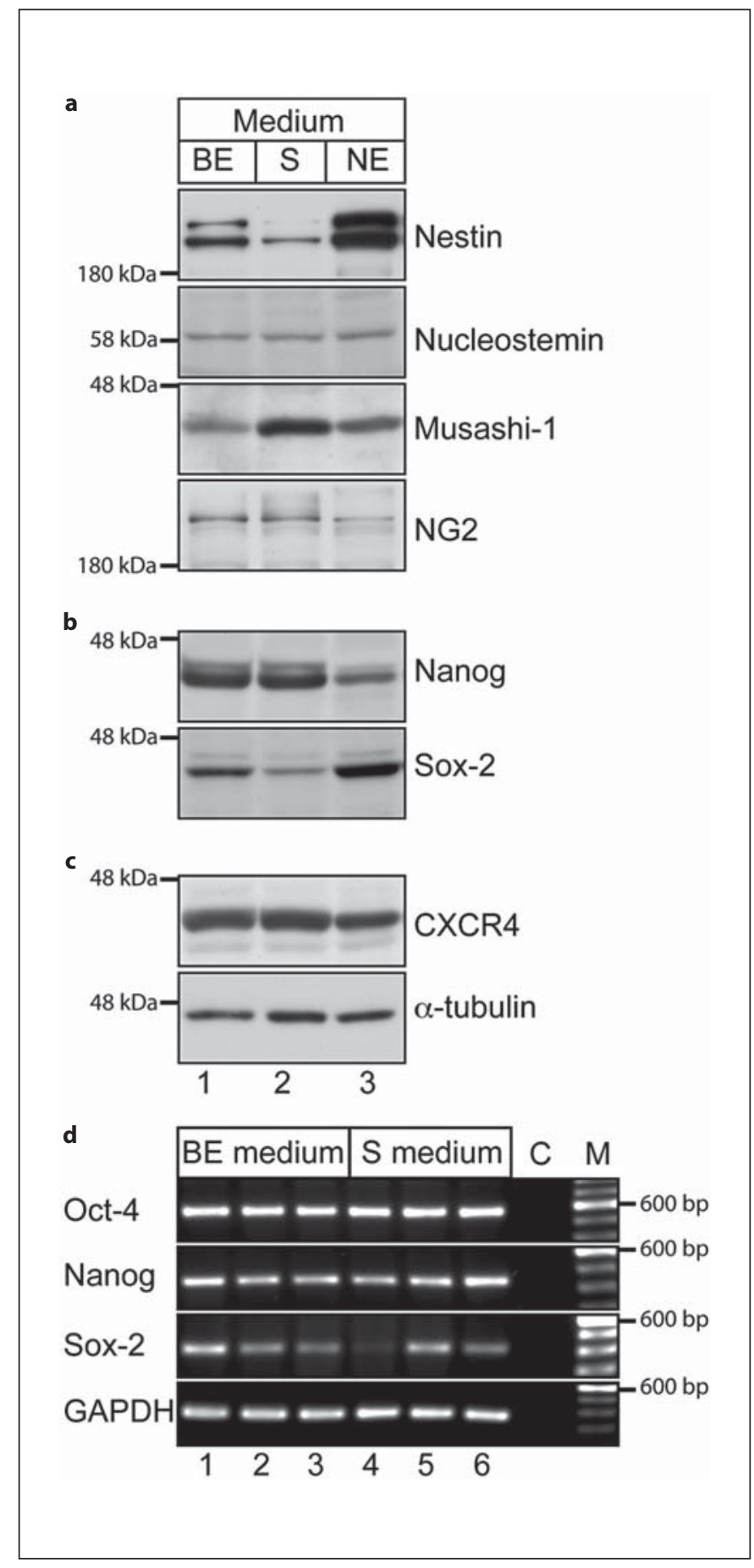

Fig. 3. Expression of neural, embryonic stem cell and other markers by DPSCs isolated and cultured in different media. The expression of neural and embryonic stem cell (a, b, respectively) and other (c) marker proteins by DPSCs, initially isolated either in basic expansion medium (BE, lane 1 ) or standard (S, lane 2) medium, was detected by immunoblotting using specific Abs. Up- or downregulation of these markers was monitored when DPSCs isolated in basic expansion medium were further cultured in neurogenic expansion medium (NE, lane 3). $\alpha$-Tubulin nestin and NG2 (fig. 5a-e, black arrowhead). The perivascular niche has been proposed as the potential source of DPSCs [Shi and Gronthos, 2003]. Second, the intranerve cells expressed $\alpha$-SMA, Musashi-1, nestin and NG2 (fig. 5a-e, blue arrowhead). The nerves were identified with Schwann cell-associated protein S-100 (fig. 5f). Third, pulpocytes found in connective tissue were positive for $\alpha$-SMA, Musashi-1, nestin and NG2 (fig. 5a-e, white arrowhead). Fourth, perineural cells surrounding nerve fibers were positive for Musashi-1, nestin and NG2 (fig. 5a-e, yellow arrowhead), whereas they lacked $\alpha$ SMA and CD146 expression (fig. 5a, b). Taken together, these data showed that dental cells expressing a certain combination of specific markers are located in different areas within dental pulp, supporting the idea of multiple sources or niches of distinct multipotent DPSCs.

\section{Differentiation Capacity of Cultured DPSCs}

Our phenotypic characterization described above suggests that dental pulp-derived cells cultured in low serum-containing media maintain a multipotential capacity, particularly with regard to the expression of early stem cell markers. Consequently, we investigated this issue by differentiating them into various cell lineages.

\section{Osteogenic and Chondrogenic Differentiation}

To evaluate mesenchymal properties of DPSCs, we tested their ability to generate either osteoblasts or chondroblasts using appropriate media and culture conditions (for details see the Materials and Methods section). In cells growing as a monolayer for 2 weeks in osteogenic medium, we detected bone-related proteins, such as procollagen I, osteonectin and osteopontin (fig. 6a-c). In multilayer nodules that were generated after 3-4 weeks (fig. 6d), collagen I fibers and deposits of calcium phosphate were observed (fig. 6e, f). Similarly, in micromass cultures, both osteonectin and collagen I were detected (fig. $6 \mathrm{~g}, \mathrm{i}$ ). In both culture conditions after 6 weeks, we detected an upregulation of osteocalcin and bone sialoprotein transcripts (fig. $6 \mathrm{~m}$ ).

was used as a loading control. The position of prestained apparent molecular mass markers is indicated on the left. A representative experiment is shown $(n=4)$. Expression of Oct-4, nanog and Sox- 2 transcripts by DPSCs isolated and cultured in basic expansion or standard medium was detected by RT-PCR (d). GAPDH was used as an internal control. $\mathrm{C}=$ Negative control, that is without cDNA template; $\mathrm{M}=100 \mathrm{bp}$ DNA ladder. Each lane (1-6) represents an independent donor; cells were approximately at the 9 th passage. 
a
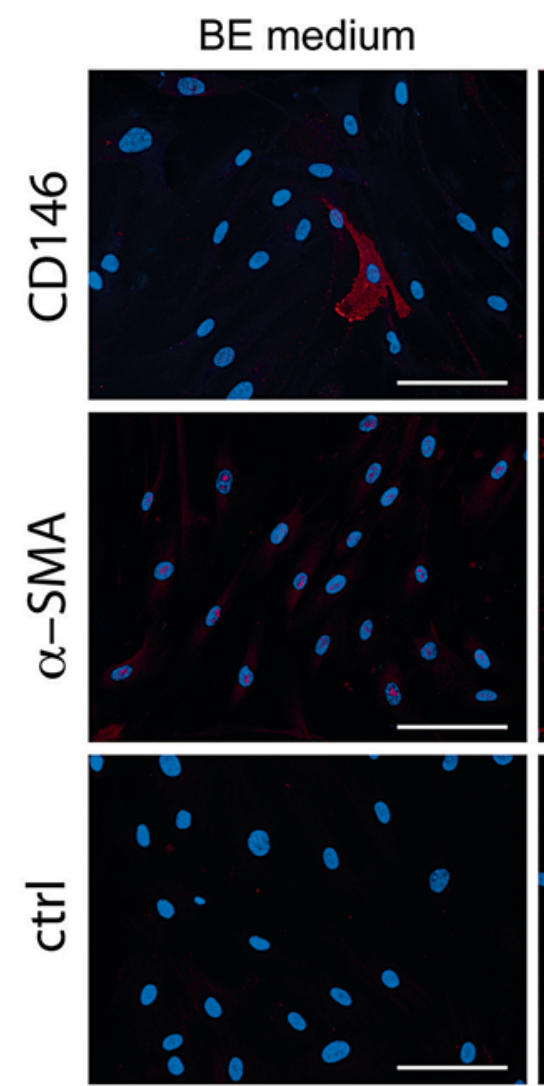

$\mathrm{BE} \rightarrow \mathrm{S}$
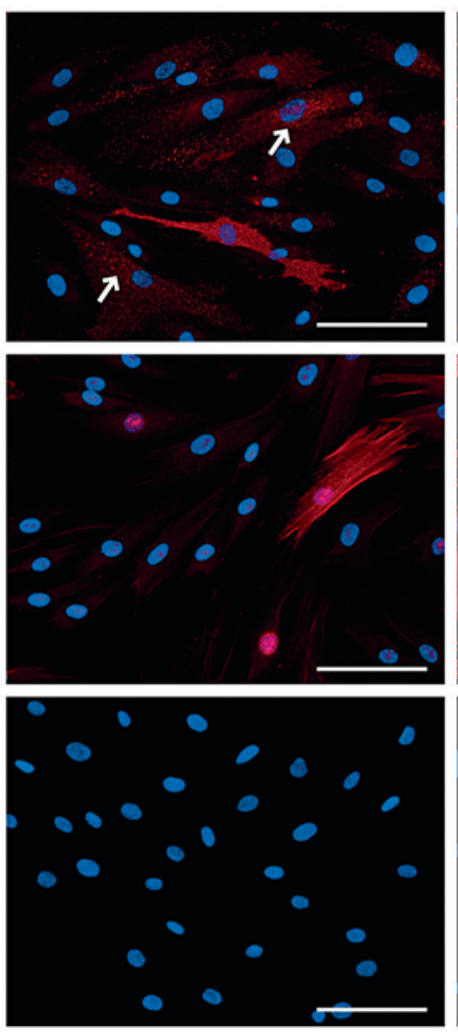

$\mathrm{S}$ medium
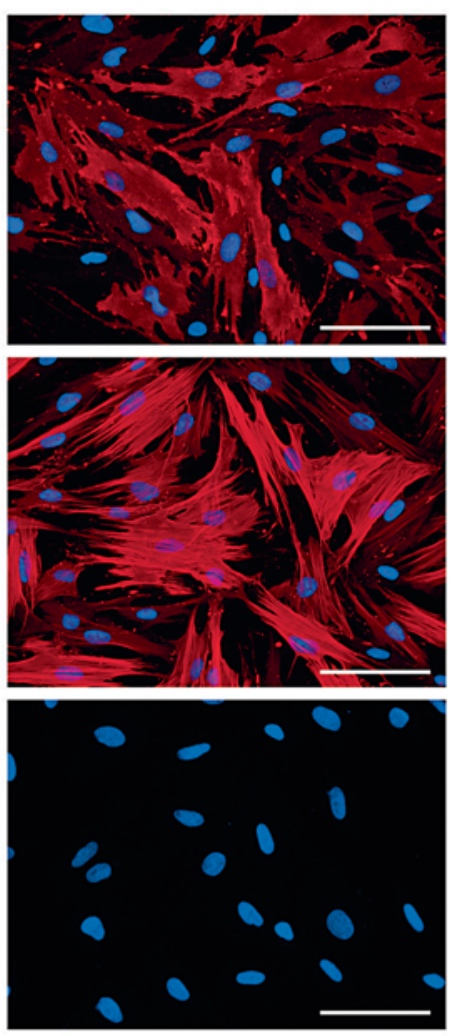

b

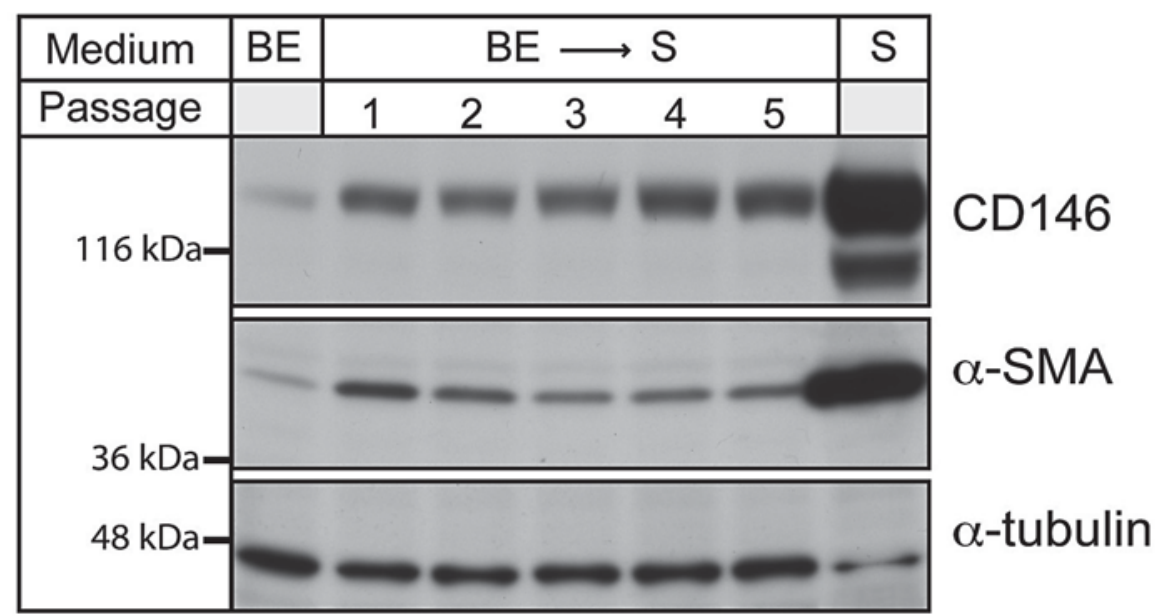
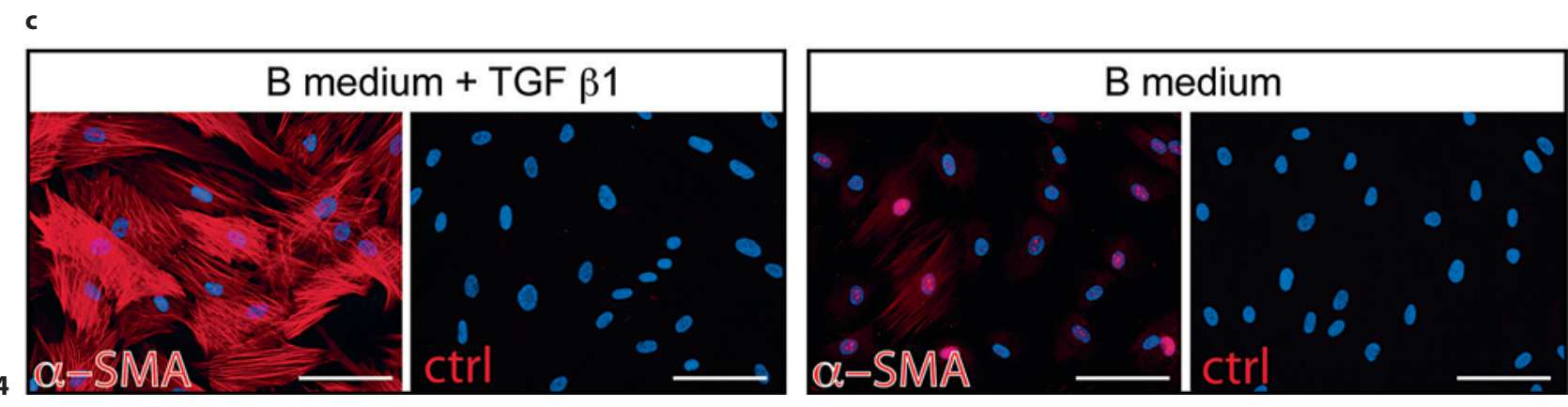
Table 4. Summary of the antigenic profile of DPSCs before and upon their differentiation

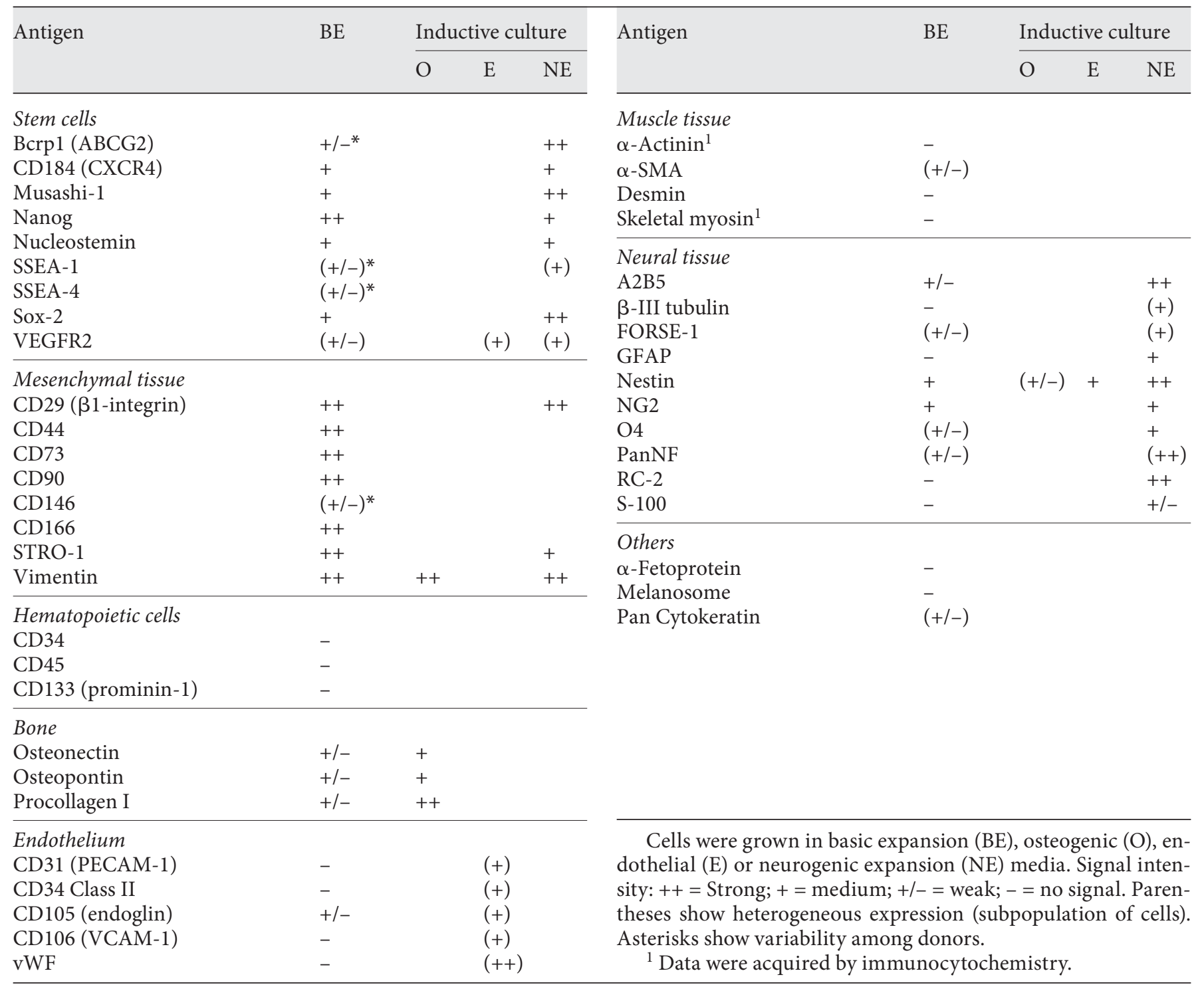

Fig. 4. Differential expression of CD146 and $\alpha$-SMA in DPSCs isolated and cultured in different media. The expression of CD146 and/or $\alpha$-SMA was monitored using immunofluorescence (a, c) and immunoblotting (b) in DPSCs isolated and cultured in basic expansion medium (BE) or standard medium (S) or cells shifted from basic expansion either to standard medium and expanded for 5 passages $(\mathbf{a}, \mathbf{b})$ or to basic medium (B) supplemented or not with TGF- $\beta 1$ and differentiated for five days (c). As a negative control (Ctrl), a Cy3 $3^{\mathrm{TM}}$-conjugated anti-mouse IgG secondary $\mathrm{Ab}$ was used alone (a, c). Nuclei were visualized with DAPI. In $\mathbf{b}, \alpha-$ tubulin was used as a loading control. The position of prestained apparent molecular mass markers is indicated on the left. Note that change of culture conditions increased CD146 and $\alpha$-SMA levels only slightly (b), and the immunoreactivity remained present only in few cells even after the 5th passage, which in the case of CD146 was represented mainly by weak dot-like positive signal (a, middle column, white arrows). A representative experiment is shown $(\mathrm{n}=3)$. Scale bars $=50 \mu \mathrm{m}$. 
In 3-week-old chondrogenic micromass bodies growing in 2 distinct chondrogenic differentiation media, we also observed acid mucin deposits characteristic of cartilaginous matrix (fig. 6j, 1). Moreover, we could detect an upregulation of collagen II and proteoglycan aggrecan transcripts (fig. 6n). Collectively, these data suggest that ex vivo expanded DPSCs generate osteoblast- and chondroblast-like cells.

\section{Endothelial Induction}

To evaluate whether DPSCs can be induced to an endothelial lineage, we cultured them in endothelial differentiation medium. Successful endothelial induction was achieved only under a proper cell plating concentration (about $2 \times 10^{4} / \mathrm{cm}^{2}$ ). Thus, after 7 days, we could detect an upregulation of von Willebrand factor, but not when the cells were seeded at a higher cell density (about $3 \times$ $10^{4} / \mathrm{cm}^{2}$; fig. $7 \mathrm{a}, \mathrm{b}$, respectively). Under low-density condition, approximately $10 \%$ of cells displayed an upregulation of the endothelial markers CD31, CD34 class II, CD105 and CD106 (fig. 7c-f; see corresponding inset for noninduced conditions). Furthermore, they maintained VEGFR2 and nestin expression (fig. 7g, h). Because cell proliferation was impaired and a downregulation of certain markers (CD31, CD34 class II and CD105) was observed during the second week of culture (data not shown), we added $10 \%$ serum after 1 week, which could restore both cell proliferation and the endothelial-like phenotype (fig. 7l-p).

\section{Smooth Muscle Cell/Myofibroblast Differentiation}

In addition to all other cell lineages described, we demonstrated that DPSCs expanded in medium containing low amounts of serum have the capacity to differentiate into smooth muscle cells/myofibroblasts. The addition of TGF- $\beta 1$ [Kleber et al., 2005] to basic medium resulted in the upregulation of $\alpha$-SMA expression with a fibrillary appearance (fig. 4c, left panels), which was not the case for basic medium alone (fig. $4 \mathrm{c}$, right panels).

Fig. 5. Potential localizations of DPSCs within the dental pulp from impacted third molars. Human dental pulp was processed for immunoperoxidase histochemistry using a panel of Abs, as indicated (a-f). As negative controls (Ctrl), either mouse isotype IgG2a (MOPC-173; g) or IgG1 (MOPC-21; h) controls were used, or the primary Ab was omitted (i). Sections were counterstained either with hematoxylin $(\mathbf{a}-\mathbf{c}, \mathbf{e}-\mathbf{i})$ or light green $(\mathbf{d})$. Dotted and dashed lines indicate arteries (a) and nerves, respectively. Con-
Table 5. The expression of various cell surface markers of undifferentiated DPSCs analyzed by flow cytometry

\begin{tabular}{lccc}
\hline Antigen & Passage No. 5-10, \% & Passage No. 15-20, \% & p value \\
\hline CD29 & $98.6(93.0 ; 98.7)$ & $97.6(78.7 ; 98.7)$ & 0.154 \\
CD34 & $0.1(0.068 ; 0.24)$ & $0.26(0.24 ; 0.72)$ & 0.343 \\
CD44 & $99.8(99.6 ; 99.9)$ & $99.5(98.8 ; 99.7)$ & 0.466 \\
CD45 & $0.28(0.17 ; 0.44)$ & $0.3(0.17 ; 0.41)$ & 0.813 \\
CD73 & $99.7(99.6 ; 99.8)$ & $99.6(99.3 ; 99.7)$ & 0.057 \\
CD90 & $99.7(99.6 ; 99.8)$ & $99.49(99.1 ; 99.6)$ & 0.057 \\
CD133 & $0.094(0.04 ; 0.27)$ & $0.19(0.15 ; 0.22)$ & 0.262 \\
CD146 & $14.8(4.23 ; 23)$ & $10.1(4.67 ; 24)$ & 0.343 \\
CD166 & $99.8(99.7 ; 99.8)$ & $99.6(98.2 ; 99.8)$ & 0.072 \\
\hline
\end{tabular}

Data are given as medians with lower and upper quartiles (in parentheses) of percentage of positive cells acquired from 10,000 events of 9 independent donors that were measured in two different culture periods as indicated. Note that there is no statistical difference of marker expression between evaluated time periods as confirmed by Wilcoxon signed-rank test ( $\mathrm{p} \leq 0.05)$.

Table 6. The expression of CD146 on undifferentiated DPSCs analyzed by flow cytometry

\begin{tabular}{lll}
\hline \multirow{2}{*}{ Donor } & \multicolumn{2}{l}{ CD146 immunoreactivity, \% } \\
\cline { 2 - 3 } & Passage No. 5-10 & Passage No. 15-20 \\
\hline 1 & 33.8 & 31.6 \\
2 & 14.8 & 10.1 \\
3 & 23 & 24 \\
4 & 0.91 & 0.2 \\
5 & 0 & 1.65 \\
6 & 17.8 & 8.89 \\
7 & 12.8 & 10.3 \\
8 & 35.5 & 37.9 \\
9 & 4.23 & 4.67 \\
\hline
\end{tabular}

Data are the percentage of CD146-positive cells acquired from 10,000 events of 9 independent donors that were measured during two different culture periods as indicated. nective tissue $(C T)$ and veins $(v)$ are indicated. Colored arrowheads show the immunoreactivity of a given protein, as indicated in the respective panel, in a particular cell type. Arrowheads: black = perivascular cells; white $=$ pulpocytes; red $=$ endothelial cells; blue = intranerve cells; yellow = perineural cells. Arrows indicate NG2 immunoreactivity in or around nerves or arteries. Asterisks indicate space created during histological preparation. Scale bars $=50 \mu \mathrm{m}$. 

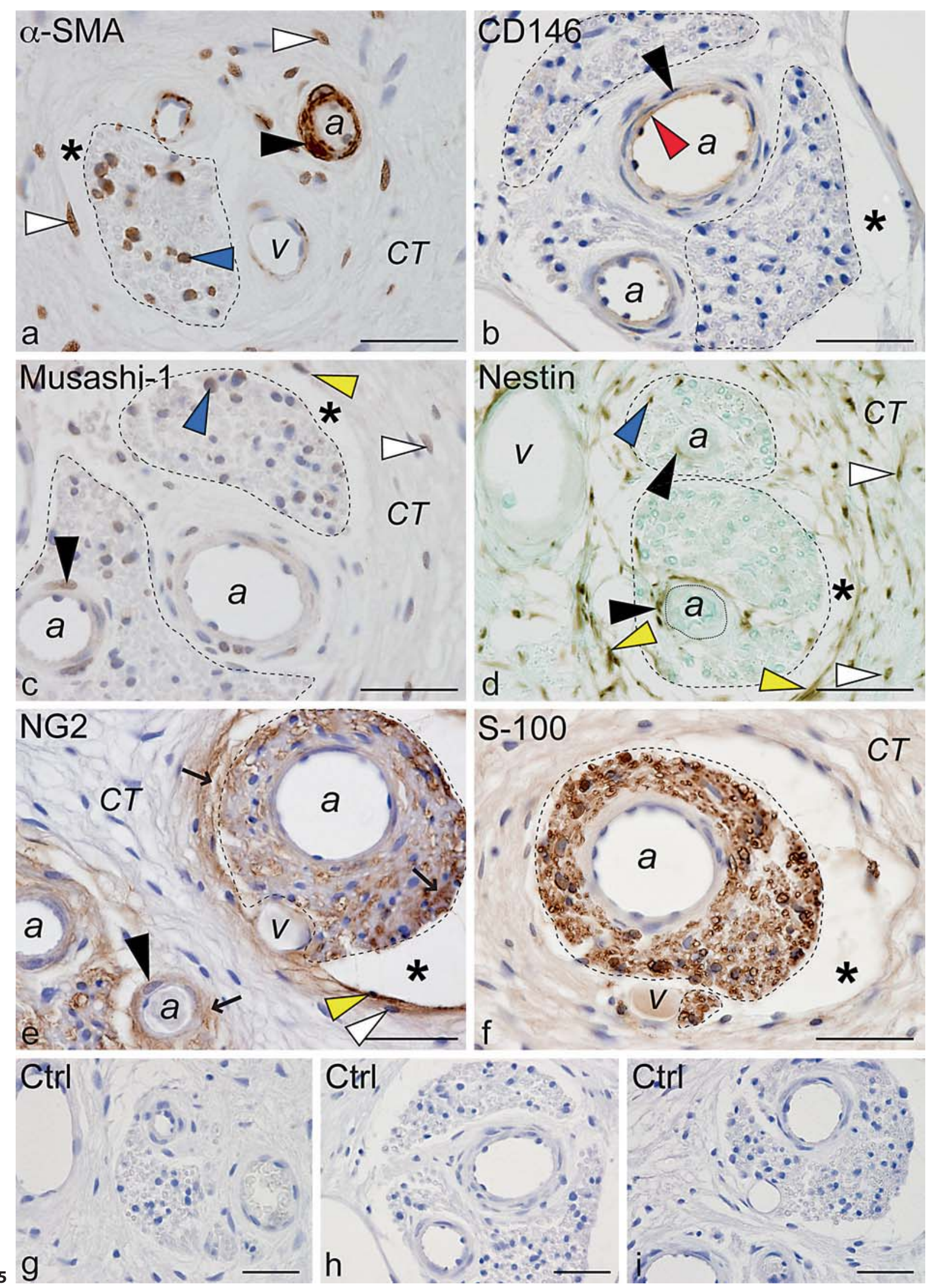


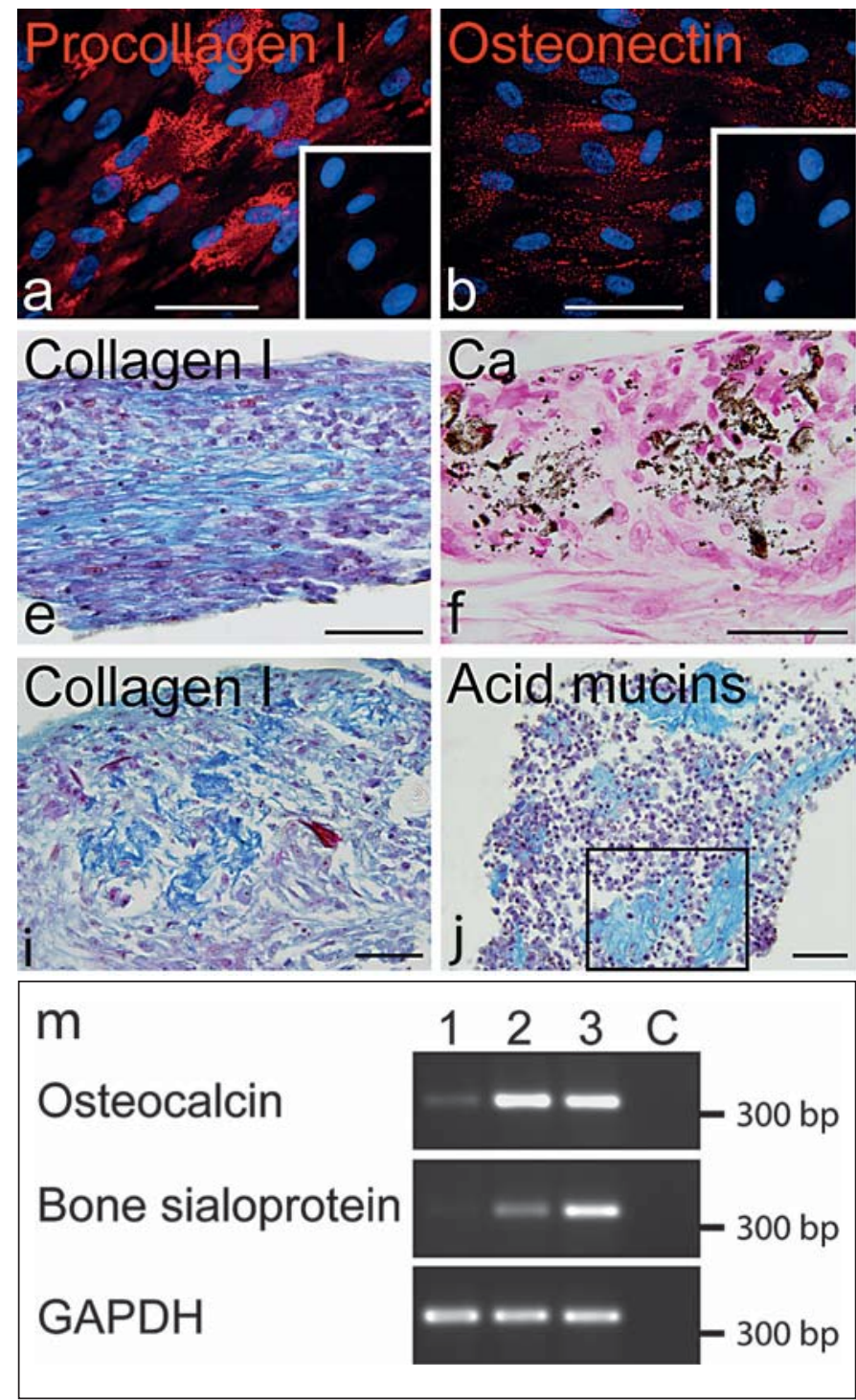

Fig. 6. Osteo- or chondro-differentiation of DPSCs. DPSCs were cultured in osteogenic $(\mathbf{a}-\mathbf{i}, \mathbf{m})$, chondrogenic A $(\mathbf{j}, \mathbf{n})$ or B $(\mathbf{I}, \mathbf{n})$ media. Two-week-old DPSC monolayers (a-c) or 3-week-old micromass bodies $(\mathbf{g}, \mathbf{i})$ were processed for immunodetection of procollagen I (a), osteonectin (b, g) and osteopontin (c). Collagen I fibers were detected using Ladewig blue trichrome (blue; i). Multilayered nodules generated after 3-4 weeks of monolayer culture were observed by phase contrast microscopy (d), and collagen I fibers and calcium phosphate $(\mathrm{Ca})$ depositions produced by them were detected using Masson's blue trichrome (blue; e) and von Kossa (black; f) staining, respectively. In 3-week-old micromass bodies (j, I), extracellular matrix-associated acid mucins were detected using Alcian blue staining. Nuclei were visualized with DAPI (a-c). Sections were counterstained with hematoxylin (e, i,
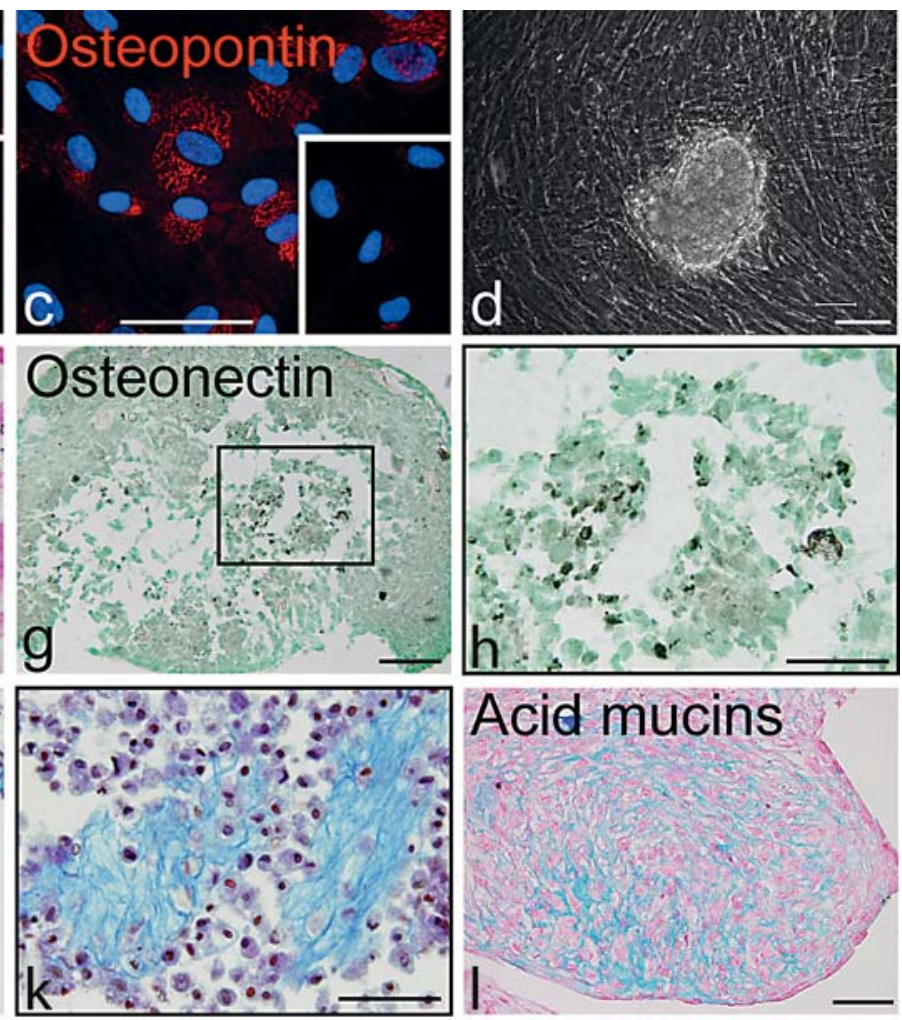

$\mathrm{n}$

Collagen II

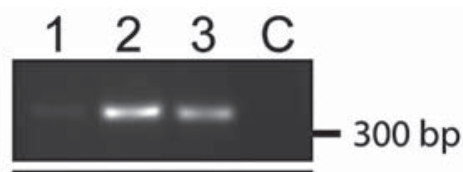

Aggrecan

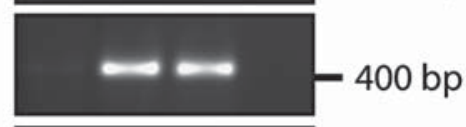

GAPDH

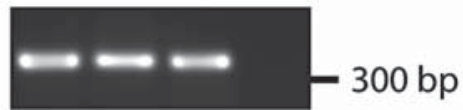

j), nuclear fast red (f, I) or light green (g). Insets in panels a-c indicate the corresponding immunodetection in noninduced cells; insets in $\mathbf{g}$ and $\mathbf{j}$ demarcate a region displayed at higher magnification in $\mathbf{h}$ and $\mathbf{k}$, respectively. RT-PCR analysis confirmed the presence of osteocalcin and bone sialoprotein transcripts in micromass and monolayer osteodifferentiation cultures ( $\mathbf{m}$, lanes 2 and 3, respectively) and collagen II and aggrecan transcripts cultured in either chondrogenic A or B media (n, lanes 2 and 3, respectively) after 6 weeks. For comparison, their transcript level in undifferentiated DPSCs is shown ( $\mathbf{m}, \mathbf{n}$, lane 1$)$. GAPDH was used as an internal control $(\mathbf{m}, \mathbf{n}) . \mathrm{C}=$ Negative control, that is without cDNA template; $\mathrm{M}=100 \mathrm{bp}$ DNA ladder. A representative experiment is shown $(n=3)$. Scale bars $=50 \mu \mathrm{m}$. 

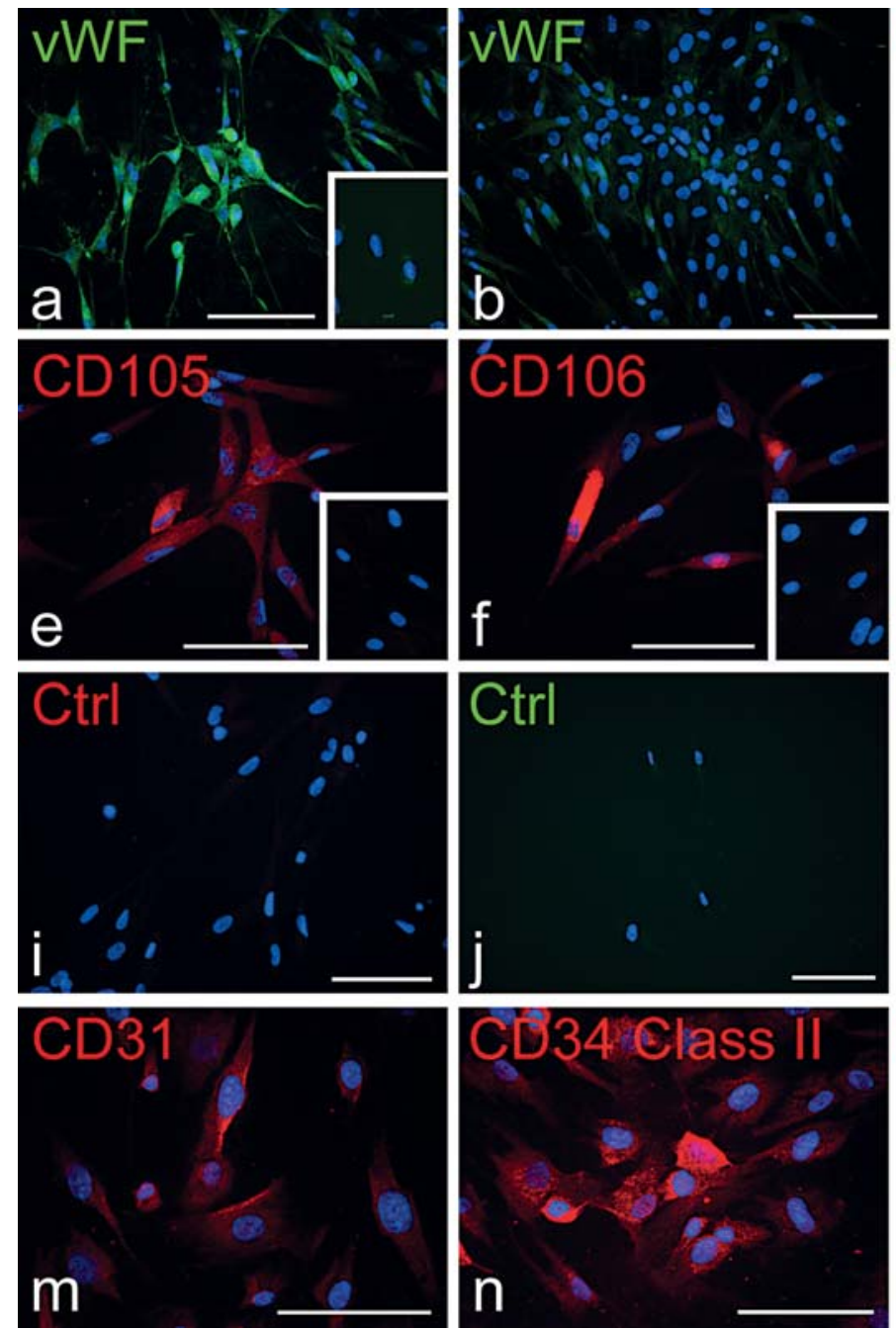

Fig. 7. Endothelial cell differentiation of DPSCs. DPSCs were initially cultured for 7 days in endothelial medium (a-k), and upon addition of $10 \%$ FCS, for an additional 10 days (I-p). Cells were plated at a density of $2 \times 10^{4} / \mathrm{cm}^{2}$ except in $\mathbf{b}$, where $3 \times 10^{4}$ cells/ $\mathrm{cm}^{2}$ were used. The expression of several endothelial markers, as indicated, was monitored by fluorescence microscopy (a-h, I-p). Insets in panels $\mathbf{a}$ and $\mathbf{c - f}$ indicate corresponding immunodetec-

\section{Differentiation Capacity to a Neural Lineage}

When grown in the neural expansion medium as a uniform cell monolayer (fig. 8a), DPSCs could proliferate for up to 14 passages without losing the expression of several stem cell markers. Under these conditions, they maintained the expression of embryonic stem cell markers (for example, nanog and Sox-2; fig. 3b, lane 1 vs. 3) and upregulated the neural/stem cell markers nestin, FORSE-1 and Bcrp1 (fig. 3a, lane 1 vs. 3; fig. 8b-d). The expression of markers of glial precursors (A2B5) and radial glial cells (RC2) was strongly increased (fig. 8e, g), whereas NG2,
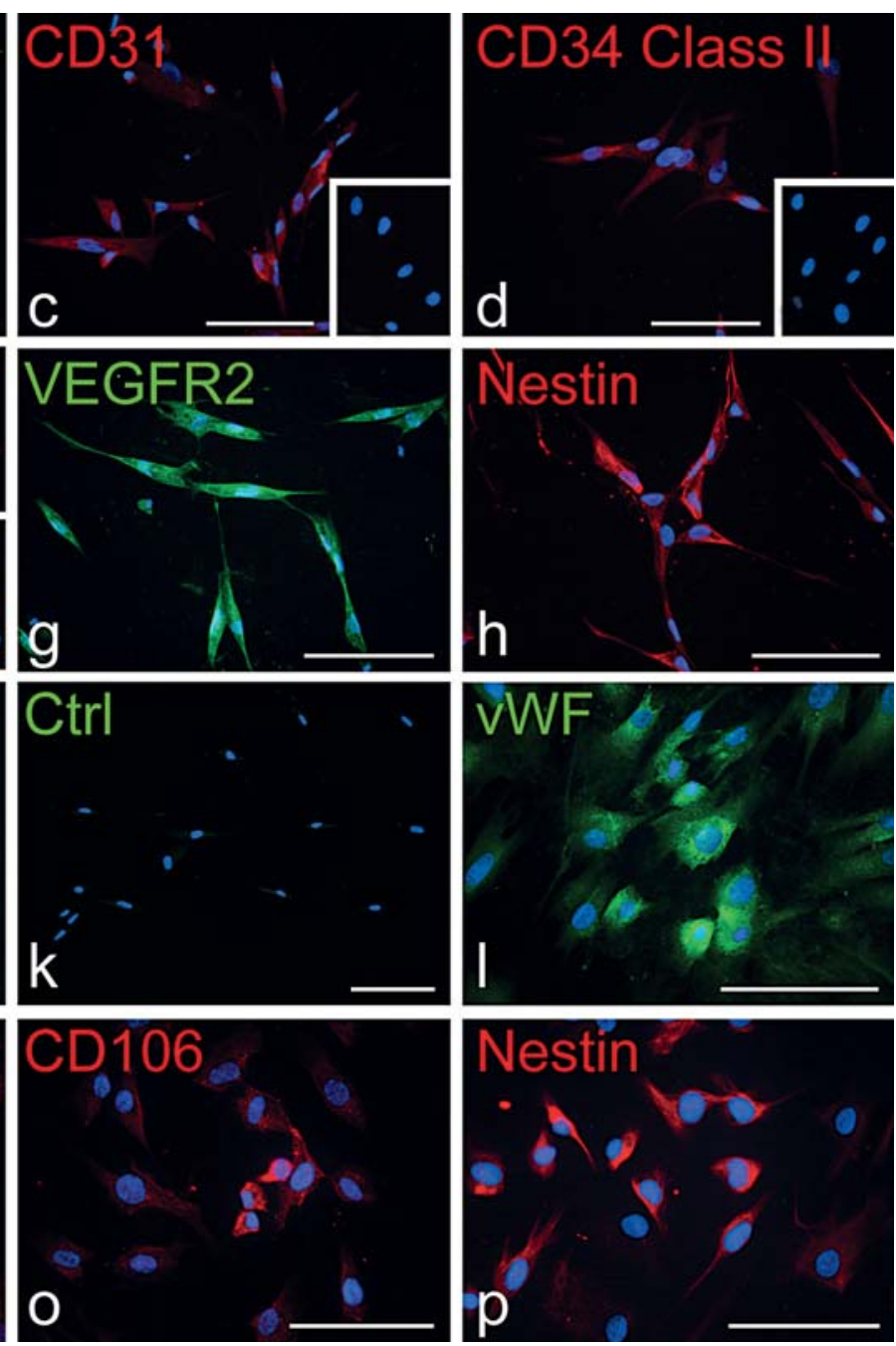

tion in noninduced cells. As negative controls (Ctrl), a Cy3-conjugated anti-mouse IgG, an Alexa Fluor 488-conjugated anti-goat or an anti-rabbit IgG secondary Ab was used alone (i-k, respectively). Nuclei were visualized with DAPI. A representative experiment is shown $(n=3)$ vWF = von Willebrand factor. Scale bars $=50 \mu \mathrm{m}$.

Musashi- 1 and nucleostemin were almost not affected (fig. 3a, lane 1 vs. 3; fig. 8f). Astrocytic (glial fibrillary acidic protein), oligodendrocytic (O4) and neuronal (PanNF, $\beta$-III tubulin) markers were expressed with a heterogeneous intensity (fig. 8h-k). PanNF- or $\beta$-III tubulin-positive cells were rare under these conditions (fig. $8 \mathrm{j}, \mathrm{k}$ ).

To stimulate neuronal differentiation, cells were further cultured either as a monolayer or spheroids. Under cell monolayer culture condition in serum-free neurogenic medium supplemented with BMP-2 [Kleber et al., 2005], the cell proliferation stopped (fig. 81) and the num- 

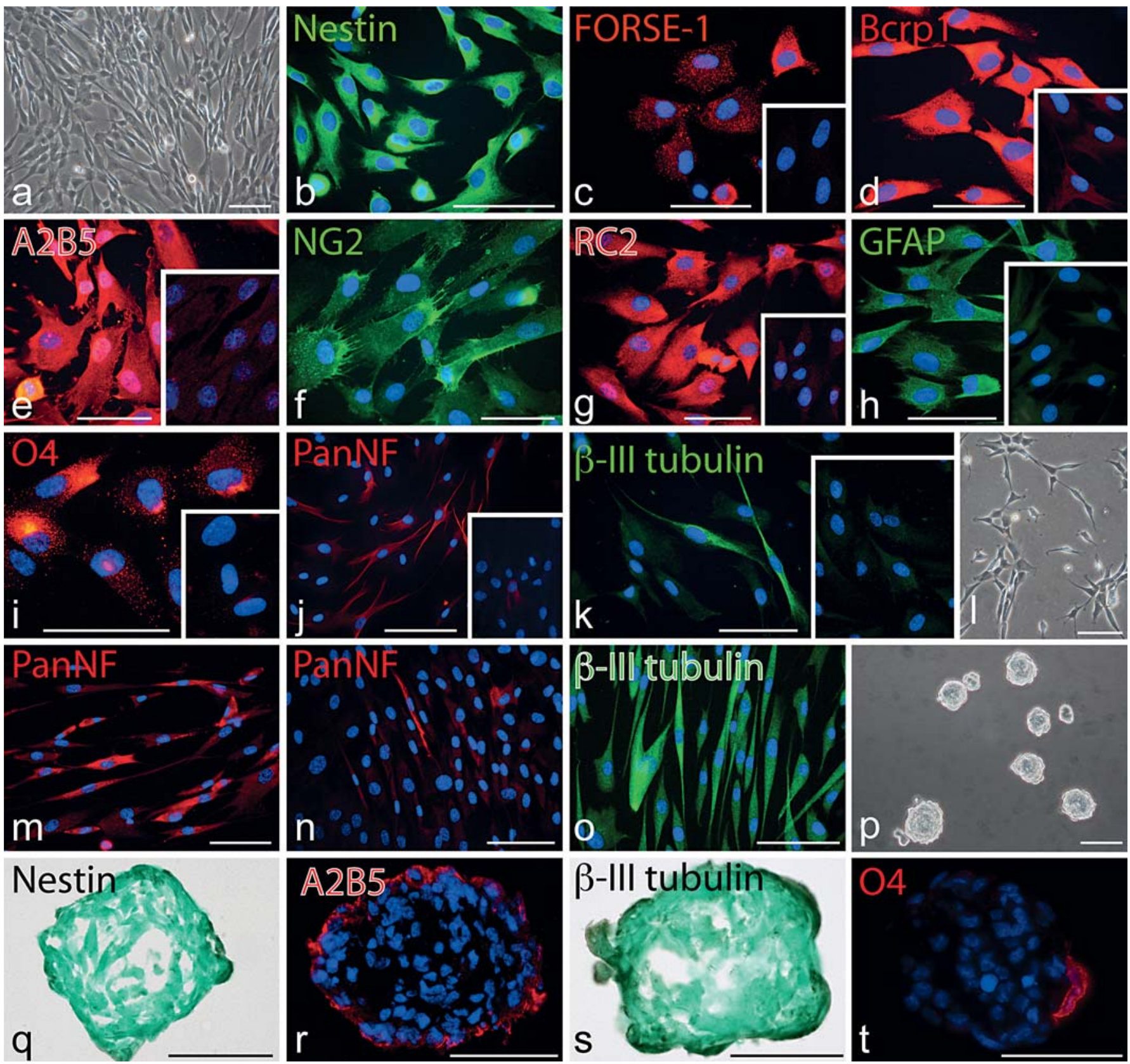

Fig. 8. Neural differentiation of DPSCs. DPSCs cultured as a cell monolayer for 3 wks in neurogenic expansion medium (a-k) were observed by phase contrast microscopy (a), and the expression of several antigenic markers, as indicated, was monitored by indirect immunofluorescence microscopy (b-k). After replating, DPSCs were further cultured for seven days in neurogenic expansion medium with $(\mathbf{n})$ or without $(\mathbf{I}, \mathbf{m}, \mathbf{o})$ serum in the presence $(\mathbf{I}-\mathbf{o})$ of BMP-2. Cells were observed by phase contrast microscopy (I), and the expression of PanNF (m, $\mathbf{n}$ ) and $\beta$-III tubulin (o) was monitored by indirect immunofluorescence microscopy. DPSCs cul-

tured as spheroids in neurogenic expansion medium were observed by phase contrast microscopy (p), and the expression of neural markers, as indicated, was monitored either by indirect immunofluorescence microscopy $(\mathbf{r}, \mathbf{t})$ or peroxidase immunohistochemistry $(\mathbf{q}, \mathbf{s})$. Insets in panels $\mathbf{c}-\mathbf{e}$ and $\mathbf{g - k}$ indicate corresponding immunodetection in noninduced cells. Nuclei were visualized with DAPI $(\mathbf{b}-\mathbf{k}, \mathbf{m}-\mathbf{o}, \mathbf{r}, \mathbf{t})$. Sections were counterstained with light green $(\mathbf{q}, \mathbf{s})$. A representative experiment is shown $(\mathrm{n}=3)$. Scale bars $=50 \mu \mathrm{m}$. 
ber of cells expressing PanNF or $\beta$-III tubulin was increased significantly (fig. $8 \mathrm{~m}, \mathrm{o}$ ). This differentiation process was inhibited when the serum (1\%) was added (fig. 8n; data not shown). In neurospheres cultured in neurogenic expansion medium, cells located at the periphery expressed markers (nestin, A2B5, $\beta$-III tubulin and $\mathrm{O} 4$ ) associated with both immature and differentiated neural cells, whereas those found in the center were negative (fig. 8q-t). Taken together, these data demonstrate that DPSCs have the capacity to generate various types of neural cells.

\section{Discussion}

In this study, we carried out extensive antigenic characterization of DPSCs isolated and expanded in media containing low amounts of serum in the presence of EGF and PDGF-BB. Moreover, we demonstrated their multipotential differentiation capacity. Because dental pulp is easily removable from teeth recovered by standard dental procedures in childhood or adulthood, and due to the excellent ex vivo proliferation capacity of DPSCs [Suchanek et al., 2007], pulp might become a valuable autologous source of somatic stem cells.

The isolation and ex vivo expansion of DPSCs in basic expansion medium containing growth factors (EGF and PDGF-BB), which were reported to have mitogenic effects on both bone marrow stromal cells [Gronthos and Simmons, 1995] and multipotent adult progenitor cells [Reyes et al., 2002], require a minimum amount of serum (2\%) to ensure their adhesion to a plastic substrate after pulp dissociation and to maintain an optimal long-term proliferation activity. However, we could observe that the number of adhered cells following isolation was lower than that recovered in media containing high amounts of serum (10-20\%, 2- to 3-fold; unpublished observations) [Suchanek et al., 2007], suggesting the media containing low amounts of serum might exert selective pressure supporting the adhesion and growth of a different and/or specific DPSC subpopulation displaying a more immature phenotype (see below). In a previous study, we demonstrated that under these culture conditions, DPSCs were able to expand for over 60 population doublings without any sign of spontaneous malignant transformation [Suchanek et al., 2007], though such transformation has been reported in long-term cultures of adult mesenchymal adipose or bone marrow stem cells [Rubio et al., 2005; Wang et al., 2005; Miura et al., 2006; Zhou et al., 2006; Rosland et al., 2009]. Coincidentally, in all of these

Characterization of Dental Pulp Stem

Cells reported cases, media containing high amounts of serum were used, which might be responsible for such cellular transformation. In agreement with this assumption, it was reported that the gene expression signature induced in fibroblasts upon exposure to $10 \%$ serum was similar to that found in cancer cells [Chang et al., 2004]. Thus, from a clinical perspective, the serum level tested here represents an interesting cellular system for the ex vivo expansion of DPSCs having a similar, but not identical, antigenic profile and differentiation properties to those generated in media containing high amounts of serum [Gronthos et al., 2000; Kerkis et al., 2006; Yalvac et al., 2010].

Our data showed that the expression profile of several stem cell-associated markers (nestin, Musashi-1, nanog, Sox-2) in DPSCs expanded in media containing low amounts of serum in the presence of EGF and PDGF-BB is highly comparable to those cultured under a condition of high amounts of serum with two notable exceptions, $\alpha$-SMA and CD146, which are poorly expressed under the former culture conditions (fig. 2, 3, 4a, b). These proteins deserve particular attention, given that they have been reported to be expressed by certain dental pulp-derived stem cells (also cultured in media containing high amounts of serum) having a clonogenic capacity [Shi and Gronthos, 2003]. Even more strikingly, CD146 may be considered as a marker of certain endothelial, pericytic, smooth muscle cells, stromal and perivascular mesenchymal stem cells [Bardin et al., 1996; Shi and Gronthos, 2003; Baksh et al., 2007; Sacchetti et al., 2007; Sorrentino et al., 2008] as well as cancer cells [Lehmann et al., 1989; Shih et al., 1996; Wu et al., 2001; Aldovini et al., 2006; Zabouo et al., 2009]. The capacity of DPSCs cultured in media containing low amounts of serum to differentiate into various lineages indicates that CD146 (as well as $\alpha$ SMA) is dispensable for this capacity and indirectly suggests that distinct pools of DPSCs may co-exist in vivo. The limited number of CD146 ( $\alpha$-SMA)-positive cells obtained here may be explained by the lack of either their initial adhesion or proliferation. Indeed, we could recover more than 65\% CD146-positive cells using a medium containing high amounts of serum (J.K., unpublished data), which is in line with the higher number of adherent cells initially obtained (see above). Moreover, the shift from low to high serum-containing media did not fully restore the expression of CD146 and $\alpha$-SMA, suggesting on the one hand that we are dealing with distinct cell populations [Verbeek et al., 1994]. On the other hand, it could not be formally excluded that using the combination of the growth factors PDGF-BB and EGF to stimulate 
the cell proliferation may also selectively inhibit their expression [Corjay et al., 1989].

Based on the expression of CD146, $\alpha$-SMA, 3G5 and STRO-1, it was proposed that DPSCs originate from the perivascular niche [Shi and Gronthos, 2003]. The differential expression of the first two markers observed here has prompted us to re-examine the possible origin of DPSCs, also considering the expression of neural progenitor markers such as Musashi-1, nestin and NG2. Our immunohistochemical analysis of immature dental pulp indicated 4 alternative, but not exclusive, DPSC sources (fig. 5). In addition to the perivascular niche, where cells with the molecular signature $\alpha$-SMA, CD146, Musashi-1, nestin and NG2 are located, DPSCs may originate from intranerve cells ( $\alpha$-SMA, Musashi-1, nestin and NG2), pulpocytes found in connective tissues ( $\alpha$-SMA, Musashi-1, nestin and NG2) or perineural cells surrounding nerve fibers (Musashi-1, nestin and NG2). Thus, considering the absence of CD146 (and eventually $\alpha$-SMA), alternative location(s) may host distinct DPSC subpopulations. Obviously, further investigations are needed to dissect the dental stem cell niche in more detail.

It was previously suggested that dental pulp originates from neural crest cells that give rise during development to dental pulp with odontoblasts and pulpocytes, cementoblasts and periodontal cells of the tooth and to multiple other tissues including facial bone and cartilage, vascular smooth muscle and peripheral nervous system [Thesleff and Aberg, 1999; Chai et al., 2000; Graham et al., 2004; Miletich and Sharpe, 2004]. It is highly probable that dental pulp contains neural crest-derived dormant stem cells that can be isolated and ex vivo expanded while maintaining their neural crest multipotential properties. In agreement with this presumption, we demonstrated that DPSCs treated with appropriate cues could differentiate into osteoblasts, chondroblasts, smooth muscle, endothelial and neural cells, as previously reported for those derived under high serum-containing conditions [Gronthos et al., 2000; Alliot-Licht et al., 2001; Miura et al., 2003; Kerkis et al., 2006; Arthur et al., 2008; Stevens et al., 2008; Nakashima et al., 2009; Yalvac et al., 2010]. In particular, endothelial cells are quite rare representatives of neural crest derivates. Only cells from the caudal part of the cranial (cardiac) neural crest are known to contribute to the formation of the endothelium and smooth muscle layer of aortic arch arteries [Waldo et al., 1998]. Nevertheless, we were able to induce the expression of certain endothelial markers, which is in line with recent studies reporting the angiogenic potential of DPSCs [Iohara et al., 2008; Marchionni et al., 2009; Nakashima et al., 2009;
Yalvac et al., 2010]. The expression of VEGFR2 (KDR, Flk-1) might explain the predisposition of these cells to respond to VEGF in differentiation conditions. Certain in vitro analyses have shown that a common VEGFR2positive vascular progenitor exists that is derived from embryonic stem cells and has the ability to differentiate into endothelial cells in the presence of VEGF and into vascular smooth muscle cells in the presence of PDGF-BB [Yamashita et al., 2000; Carmeliet, 2004]. This is in agreement with our data showing that the stimulation of DPSCs with appropriate growth factors gave rise to cells with a phenotype of endothelial cells or $\alpha$-SMA-positive smooth muscle cells.

Finally, we showed that DPSCs can be committed to the neural lineage and further propagated in the neurogenic expansion medium while preserving or upregulating the expression of neural markers including Sox-2 [Zappone et al., 2000; Ellis et al., 2004], nucleostemin [Tsai and McKay, 2002], Musashi-1 [Kaneko et al., 2000], nestin [Lendahl et al., 1990] and LeX/FORSE-1/SSEA-1 [Allendoerfer et al., 1995; Capela and Temple, 2006; Pruszak et al., 2007]. This molecular profile, together with the upregulation of Bcrp1, is characteristic not only of neural stem cells, but also of neural crest stem cells isolated from different sources in mice [Tomita et al., 2005; Yoshida et al., 2006] or humans [Thomas et al., 2008]. Furthermore, we observed that DPSCs could be induced under appropriate culture conditions to a neuronal phenotype similar to those derived from high serum-content media conditions in which they were found to differentiate to functionally active neurons [Arthur et al., 2008]. Other studies have documented that DPSCs secrete many neurotrophic growth factors, such as BDNF, CNTF, FGF, GDNF, NGF and VEGF, which were found to promote neuronal rescue and survival, neurite outgrowth and guidance in vitro and in vivo [Nosrat et al., 2001; Nosrat et al., 2004; Arthur et al., 2009] and to stimulate neurogenesis after transplantation in the hippocampus [Huang et al., 2008]. These new facets of DPSCs present the exciting possibility of using this primary cell culture system as a starting point in further studies aimed at the derivation of neuronal cells that could be employed in therapies of neurodegenerative disorders. However, it is important to mention that, in contrast to stem cells derived from the central nervous system, the efficient growth of DPSCs on three-dimensional structures, such as spheroids, was achieved only in the presence of serum. Furthermore, on spheroids, only peripheral cells maintained the expression of both immature and mature neural markers, whereas those located centrally, which were expected to 
differentiate into glial and neuronal cells as in conventional neurospheres [Mokry et al., 2008], lacked them. Thus, the behavior of DPSCs on three-dimensional structures seems to somehow be different from primitive cells derived from the central nervous system.

In conclusion, our data indicate that isolated DPSCs cultured in media containing low amounts of serum in the presence of EGF and PDGF-BB simultaneously share the antigenic profile of mesenchymal and neural stem cells and, furthermore, express certain markers of embryonic stem cells. Additionally, we showed that these cells have the capacity to generate multiple lineages. In particular, the possibility of expanding DPSCs committed to a neural lineage and specifically differentiating them further represents a new direction in the field of tissue engineering and therapy of neurodegenerative disorders based on utilizing non-central nervous system cells. Further studies focusing on the directed differentiation of DPSCs into specific neuronal cells, their possible trophic support of degenerating neurons and their general neurosecretoric activity might result in new advances in treatment of, for example, Parkinson's disease. Moreover, the differential expression of CD146 and $\alpha$-SMA observed between cells isolated and expanded in low versus high serum-content media suggest that distinct multipotent stem cells might co-exist within the dental pulp. It will be of interest to determine the transcriptome and/or proteome of both the positive versus negative subpopulations of CD146 (or $\alpha$-SMA). Collectively, the ready availability of these cells, an easy isolation process and the unique culture characteristics of this innovative culture system make DPSCs a possible reliable source of somatic stem cells that might be considered for use in tissue engineering and cell-based replacement.

\section{Acknowledgments}

J.K. is supported by the Grant Agency of the Czech Republic (GACR 304/07/P307), J.K., T.S., J.S. and J.M. are supported by the Internal Grant Agency of the Ministry of Health of the Czech Republic No. 9182-3/07 (IGA MZ) and D.C. is supported by the Deutsche Forschungsgemeinschaft (DFG, SFB 655, B3; TRR83, No. 6).

\section{References}

Aldovini, D., F. Demichelis, C. Doglioni, D. Di Vizio, E. Galligioni, S. Brugnara, B. Zeni, C. Griso, C. Pegoraro, M. Zannoni, M. Gariboldi, E. Balladore, D. Mezzanzanica, S. Canevari, M. Barbareschi (2006) M-CAM expression as marker of poor prognosis in epithelial ovarian cancer. Int J Cancer 119: $1920-1926$.

Allendoerfer, K.L., J.L. Magnani, P.H. Patterson (1995) FORSE-1, an antibody that labels regionally restricted subpopulations of progenitor cells in the embryonic central nervous system, recognizes the $\operatorname{Le}(\mathrm{x})$ carbohydrate on a proteoglycan and two glycolipid antigens. Mol Cell Neurosci 6: 381-395.

Alliot-Licht, B., D. Hurtrel, M. Gregoire (2001) Characterization of $\alpha$-smooth muscle actin positive cells in mineralized human dental pulp cultures. Arch Oral Biol 46: 221-228.

Arthur, A., G. Rychkov, S. Shi, S.A. Koblar, S. Gronthos (2008) Adult human dental pulp stem cells differentiate toward functionally active neurons under appropriate environmental cues. Stem Cells 26: 1787-1795.

Arthur, A., S. Shi, A.C. Zannettino, N. Fujii, S. Gronthos, S.A. Koblar (2009) Implanted adult human dental pulp stem cells induce endogenous axon guidance. Stem Cells 27: 2229-2237.

Characterization of Dental Pulp Stem Cells
Baksh, D., R. Yao, R.S. Tuan (2007) Comparison of proliferative and multilineage differentiation potential of human mesenchymal stem cells derived from umbilical cord and bone marrow. Stem Cells 25: 1384-1392.

Bardin, N., F. George, M. Mutin, C. Brisson, N. Horschowski, V. Frances, G. Lesaule, J. Sampol (1996) S-Endo 1, a pan-endothelial monoclonal antibody recognizing a novel human endothelial antigen. Tissue Antigens 48: 531-539.

Capela, A., S. Temple (2006) LeX is expressed by principle progenitor cells in the embryonic nervous system, is secreted into their environment and binds Wnt-1. Dev Biol 291: 300-313.

Carmeliet, P. (2004) Manipulating angiogenesis in medicine. J Intern Med 255: 538-561.

Corbeil, D., C.A. Fargeas, W.B. Huttner (2001) Rat prominin, like its mouse and human orthologues, is a pentaspan membrane glycoprotein. Biochem Biophys Res Commun 285: 939-944.

Corbeil, D., K. Röper, A. Hellwig, M. Tavian, S. Miraglia, S.M. Watt, P.J. Simmons, B. Peault, D.W. Buck, W.B. Huttner (2000) The human AC133 hematopoietic stem cell antigen is also expressed in epithelial cells and targeted to plasma membrane protrusions. J Biol Chem 275: 5512-5520.
Corjay, M.H., M.M. Thompson, K.R. Lynch, G.K. Owens (1989) Differential effect of platelet-derived growth factor- versus serum-induced growth on smooth muscle alpha-actin and nonmuscle beta-actin mRNA expression in cultured rat aortic smooth muscle cells. J Biol Chem 264: 10501-10506.

Ellis, P., B.M. Fagan, S.T. Magness, S. Hutton, O. Taranova, S. Hayashi, A. McMahon, M. Rao, L. Pevny (2004) SOX2, a persistent marker for multipotential neural stem cells derived from embryonic stem cells, the embryo or the adult. Dev Neurosci 26: 148-165.

Gou, S., C. Wang, T. Liu, H. Wu, J. Xiong, F. Zhou, G. Zhao (2010) Spontaneous differentiation of murine bone marrow-derived mesenchymal stem cells into adipocytes without malignant transformation after long-term culture. Cells Tissues Organs 191: 185-192.

Graham, A., J. Begbie, I. McGonnell (2004) Significance of the cranial neural crest. Dev Dyn 229: 5-13.

Gronthos, S., J. Brahim, W. Li, L.W. Fisher, N. Cherman, A. Boyde, P. DenBesten, P.G. Robey, S. Shi (2002) Stem cell properties of human dental pulp stem cells. J Dent Res 81: 531-535. 
Gronthos, S., M. Mankani, J. Brahim, P.G. Robey, S. Shi (2000) Postnatal human dental pulp stem cells (DPSCs) in vitro and in vivo. Proc Natl Acad Sci USA 97: 13625-13630.

Gronthos, S., P.J. Simmons (1995) The growth factor requirements of STRO-1-positive human bone marrow stromal precursors under serum-deprived conditions in vitro. Blood 85: 929-940.

Huang, A.H., B.R. Snyder, P.H. Cheng, A.W. Chan (2008) Putative dental pulp-derived stem/stromal cells promote proliferation and differentiation of endogenous neural cells in the hippocampus of mice. Stem Cells 26: 2654-2663.

Chai, Y., X. Jiang, Y. Ito, P. Bringas, Jr., J. Han, D.H. Rowitch, P. Soriano, A.P. McMahon, H.M. Sucov (2000) Fate of the mammalian cranial neural crest during tooth and mandibular morphogenesis. Development 127: 1671-1679.

Chang, H.Y., J.B. Sneddon, A.A. Alizadeh, R. Sood, R.B. West, K. Montgomery, J.T. Chi, M. van de Rijn, D. Botstein, P.O. Brown (2004) Gene expression signature of fibroblast serum response predicts human cancer progression: similarities between tumors and wounds. PLoS Biol 2: E7.

Iohara, K., L. Zheng, H. Wake, M. Ito, J. Nabekura, H. Wakita, H. Nakamura, T. Into, K. Matsushita, M. Nakashima (2008) A novel stem cell source for vasculogenesis in ischemia: subfraction of side population cells from dental pulp. Stem Cells 26: 2408-2418.

Kaneko, Y., S. Sakakibara, T. Imai, A. Suzuki, Y. Nakamura, K. Sawamoto, Y. Ogawa, Y. Toyama, T. Miyata, H. Okano (2000) Musashi1: an evolutionally conserved marker for CNS progenitor cells including neural stem cells. Dev Neurosci 22: 139-153.

Kerkis, I., A. Kerkis, D. Dozortsev, G.C. StukartParsons, S.M. Gomes Massironi, L.V. Pereira, A.I. Caplan, H.F. Cerruti (2006) Isolation and characterization of a population of immature dental pulp stem cells expressing OCT- 4 and other embryonic stem cell markers. Cells Tissues Organs 184: 105-116.

Kleber, M., H.Y. Lee, H. Wurdak, J. Buchstaller, M.M. Riccomagno, L.M. Ittner, U. Suter, D.J. Epstein, L. Sommer (2005) Neural crest stem cell maintenance by combinatorial Wnt and BMP signaling. J Cell Biol 169: 309-320.

Kudo, Y., M. Iwashita, Y. Takeda, T. Muraki (1998) Evidence for modulation of osteocalcin containing gamma-carboxyglutamic acid residues synthesis by insulin-like growth factor-I and vitamin K2 in human osteosarcoma cell line MG-63. Eur J Endocrinol 138: 443-448.

Lehmann, J.M., G. Riethmuller, J.P. Johnson (1989) MUC18, a marker of tumor progression in human melanoma, shows sequence similarity to the neural cell adhesion molecules of the immunoglobulin superfamily. Proc Natl Acad Sci USA 86: 9891-9895.
Lendahl, U., L.B. Zimmerman, R.D. McKay (1990) CNS stem cells express a new class of intermediate filament protein. Cell 60: 585595.

Mackay, A.M., S.C. Beck, J.M. Murphy, F.P. Barry, C.O. Chichester, M.F. Pittenger (1998) Chondrogenic differentiation of cultured human mesenchymal stem cells from marrow. Tissue Eng 4: 415-428.

Marchionni, C., L. Bonsi, F. Alviano, G. Lanzoni, A. Di Tullio, R. Costa, M. Montanari, P.L. Tazzari, F. Ricci, G. Pasquinelli, C. Orrico, A. Grossi, C. Prati, G.P. Bagnara (2009) Angiogenic potential of human dental pulp stromal (stem) cells. Int J Immunopathol Pharmacol 22: 699-706.

McLaughlin, D., E. Tsirimonaki, G. Vallianatos, N. Sakellaridis, T. Chatzistamatiou, C. Stavropoulos-Gioka, A. Tsezou, I. Messinis, D. Mangoura (2006) Stable expression of a neuronal dopaminergic progenitor phenotype in cell lines derived from human amniotic fluid cells. J Neurosci Res 83: 1190-1200.

Miletich, I., P.T. Sharpe (2004) Neural crest contribution to mammalian tooth formation. Birth Defects Res C Embryo Today 72: 200212.

Miura, M., S. Gronthos, M. Zhao, B. Lu, L.W. Fisher, P.G. Robey, S. Shi (2003) SHED: stem cells from human exfoliated deciduous teeth. Proc Natl Acad Sci USA 100: 5807-5812.

Miura, M., Y. Miura, H.M. Padilla-Nash, A.A. Molinolo, B. Fu, V. Patel, B.M. Seo, W. Sonoyama, J.J. Zheng, C.C. Baker, W. Chen, T. Ried, S. Shi (2006) Accumulated chromosomal instability in murine bone marrow mesenchymal stem cells leads to malignant transformation. Stem Cells 24: 1095-1103.

Mokry, J., J. Karbanova, S. Filip, D. Cizkova, J. Pazour, D. English (2008) Phenotypic and morphological characterization of in vitro oligodendrogliogenesis. Stem Cells Dev 17: 333-341.

Nakashima, M., K. Iohara, M. Sugiyama (2009) Human dental pulp stem cells with highly angiogenic and neurogenic potential for possible use in pulp regeneration. Cytokine Growth Factor Rev 20: 435-440.

Nosrat, I.V., C.A. Smith, P. Mullally, L. Olson, C.A. Nosrat (2004) Dental pulp cells provide neurotrophic support for dopaminergic neurons and differentiate into neurons in vitro; implications for tissue engineering and repair in the nervous system. Eur J Neurosci 19: 2388-2398.

Nosrat, I.V., J. Widenfalk, L. Olson, C.A. Nosrat (2001) Dental pulp cells produce neurotrophic factors, interact with trigeminal neurons in vitro, and rescue motoneurons after spinal cord injury. Dev Biol 238: 120132.

Pittenger, M.F., A.M. Mackay, S.C. Beck, R.K. Jaiswal, R. Douglas, J.D. Mosca, M.A. Moorman, D.W. Simonetti, S. Craig, D.R. Marshak (1999) Multilineage potential of adult human mesenchymal stem cells. Science 284 : 143-147.
Pruszak, J., K.C. Sonntag, M.H. Aung, R. Sanchez-Pernaute, O. Isacson (2007) Markers and methods for cell sorting of human embryonic stem cell-derived neural cell populations. Stem Cells 25: 2257-2268.

Reyes, M., A. Dudek, B. Jahagirdar, L. Koodie, P.H. Marker, C.M. Verfaillie (2002) Origin of endothelial progenitors in human postnatal bone marrow. J Clin Invest 109: 337-346.

Rosland, G.V., A. Svendsen, A. Torsvik, E. Sobala, E. McCormack, H. Immervoll, J. Mysliwietz, J.C. Tonn, R. Goldbrunner, P.E. Lonning, R. Bjerkvig, C. Schichor (2009) Long-term cultures of bone marrow-derived human mesenchymal stem cells frequently undergo spontaneous malignant transformation. Cancer Res 69: 5331-5339.

Rubio, D., J. Garcia-Castro, M.C. Martin, R. de la Fuente, J.C. Cigudosa, A.C. Lloyd, A. Bernad (2005) Spontaneous human adult stem cell transformation. Cancer Res 65: 30353039.

Sacchetti, B., A. Funari, S. Michienzi, S. Di Cesare, S. Piersanti, I. Saggio, E. Tagliafico, S. Ferrari, P.G. Robey, M. Riminucci, P. Bianco (2007) Self-renewing osteoprogenitors in bone marrow sinusoids can organize a hematopoietic microenvironment. Cell 131: 324-336.

Shi, S., S. Gronthos (2003) Perivascular niche of postnatal mesenchymal stem cells in human bone marrow and dental pulp. J Bone Miner Res 18: 696-704.

Shih, I.M., T.L. Wang, W.H. Westra (1996) Diagnostic and biological implications of melCAM expression in mesenchymal neoplasms. Clin Cancer Res 2: 569-575.

Sorrentino, A., M. Ferracin, G. Castelli, M. Biffoni, G. Tomaselli, M. Baiocchi, A. Fatica, M. Negrini, C. Peschle, M. Valtieri (2008) Isolation and characterization of CD146+ multipotent mesenchymal stromal cells. Exp Hematol 36: 1035-1046.

Stevens, A., T. Zuliani, C. Olejnik, H. LeRoy, H. Obriot, J. Kerr-Conte, P. Formstecher, Y. Bailliez, R.R. Polakowska (2008) Human dental pulp stem cells differentiate into neural crest-derived melanocytes and have label-retaining and sphere-forming abilities. Stem Cells Dev 17: 1175-1184.

Suchanek, J., T. Soukup, R. Ivancakova, J. Karbanova, V. Hubkova, R. Pytlik, L. Kucerova (2007) Human dental pulp stem cells - isolation and long term cultivation. Acta Medica (Hradec Kralove) 50: 195-201.

Thesleff, I., T. Aberg (1999) Molecular regulation of tooth development. Bone 25: 123-125.

Thomas, S., M. Thomas, P. Wincker, C. Babarit, P. Xu, M.C. Speer, A. Munnich, S. Lyonnet, M. Vekemans, H.C. Etchevers (2008) Human neural crest cells display molecular and phenotypic hallmarks of stem cells. Hum Mol Genet 17: 3411-3425. 
Tomita, Y., K. Matsumura, Y. Wakamatsu, Y. Matsuzaki, I. Shibuya, H. Kawaguchi, M. Ieda, S. Kanakubo, T. Shimazaki, S. Ogawa, N. Osumi, H. Okano, K. Fukuda (2005) Cardiac neural crest cells contribute to the dormant multipotent stem cell in the mammalian heart. J Cell Biol 170: 1135-1146.

Tsai, R.Y., R.D. McKay (2002) A nucleolar mechanism controlling cell proliferation in stem cells and cancer cells. Genes Dev 16: 29913003.

Tseng, P.Y., C.J. Chen, C.C. Sheu, C.W. Yu, Y.S. Huang (2007) Spontaneous differentiation of adult rat marrow stromal cells in a longterm culture. J Vet Med Sci 69: 95-102.

Verbeek, M.M., I. Otte-Holler, P. Wesseling, D.J. Ruiter, R.M. de Waal (1994) Induction of alpha-smooth muscle actin expression in cultured human brain pericytes by transforming growth factor-beta 1. Am J Pathol 144: 372-382.

Waldo, K., S. Miyagawa-Tomita, D. Kumiski, M.L. Kirby (1998) Cardiac neural crest cells provide new insight into septation of the cardiac outflow tract: aortic sac to ventricular septal closure. Dev Biol 196: 129-144.
Wang, Y., D.L. Huso, J. Harrington, J. Kellner, D.K. Jeong, J. Turney, I.K. McNiece (2005) Outgrowth of a transformed cell population derived from normal human BM mesenchymal stem cell culture. Cytotherapy 7: 509519.

Wu, G.J., V.A. Varma, M.W. Wu, S.W. Wang, P. Qu, H. Yang, J.A. Petros, S.D. Lim, M.B. Amin (2001) Expression of a human cell adhesion molecule, MUC18, in prostate cancer cell lines and tissues. Prostate 48: 305-315.

Yalvac, M.E., M. Ramazanoglu, A.A. Rizvanov, F. Sahin, O.F. Bayrak, U. Salli, A. Palotas, G.T. Kose (2010) Isolation and characterization of stem cells derived from human third molar tooth germs of young adults: implications in neo-vascularization, osteo-, adipoand neurogenesis. Pharmacogenomics J 10: 105-113.

Yamashita, J., H. Itoh, M. Hirashima, M. Ogawa, S. Nishikawa, T. Yurugi, M. Naito, K. Nakao, S. Nishikawa (2000) Flk1-positive cells derived from embryonic stem cells serve as vascular progenitors. Nature 408: 92-96.

Yoshida, S., S. Shimmura, N. Nagoshi, K. Fukuda, Y. Matsuzaki, H. Okano, K. Tsubota (2006) Isolation of multipotent neural crestderived stem cells from the adult mouse cornea. Stem Cells 24: 2714-2722.
Zabouo, G., A.M. Imbert, J. Jacquemier, P. Finetti, T. Moreau, B. Esterni, D. Birnbaum, F. Bertucci, C. Chabannon (2009) CD146 expression is associated with a poor prognosis in human breast tumors and with enhanced motility in breast cancer cell lines. Breast Cancer Res 11: R1.

Zappone, M.V., R. Galli, R. Catena, N. Meani, S. De Biasi, E. Mattei, C. Tiveron, A.L. Vescovi, R. Lovell-Badge, S. Ottolenghi, S.K. Nicolis (2000) Sox 2 regulatory sequences direct expression of a $(\beta)$-geo transgene to telencephalic neural stem cells and precursors of the mouse embryo, revealing regionalization of gene expression in CNS stem cells. Development 127: 2367-2382.

Zhou, Y.F., M. Bosch-Marce, H. Okuyama, B. Krishnamachary, H. Kimura, L. Zhang, D.L. Huso, G.L. Semenza (2006) Spontaneous transformation of cultured mouse bone marrow-derived stromal cells. Cancer Res 66: 10849-10854. 